\title{
1830’’u Yıllarda Osmanlı’da İç Göç: Üsküp Örneği
}

\section{Internal Migration in The Ottoman Empire in the 1830s: The Example of Skopje}

\author{
Nedim İpek ${ }^{*}$ (1)
}

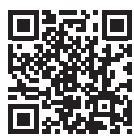

*Prof. Dr., Ondokuz Mayıs Üniversitesi, Fen-Edebiyat Fakültesi, Tarih Bölümü, Samsun, Türkiye

ORCID: N.İ. 0000-0001-9239-1333

Sorumlu yazar/Corresponding author: Nedim İpek,

Ondokuz Mayıs Üniversitesi, Fen-Edebiyat Fakültesi, Tarih Bölümü, Samsun, Türkiye

E-posta/E-mail: nipek@omu.edu.tr

Başvuru/Submitted: 17.03 .2020 Revizyon Talebi/Revision Requested: 18.06.2020

Son Revizyon/Last Revision Received: 28.06.2020

Kabul/Accepted: 15.07 .2020

\section{Atıf/Citation:}

Ipek, Nedim. "1830'lu Yıllarda Osmanlı'da İç Göç: Üsküp Örneği." Tarih Dergisi - Turkish Journal of History, 71 (2020): 255-280.

https://doi.org/10.26650/TurkJHist.2020.015 öz

Yurtiçi göç, aynı ülke sınırları içinde bir yerden başka bir yere seyahat eden insanların geçici veya kalııı sürecini ifade eder. Üsküp ve iç bölgelerinde yaşayanlar geçimlerini tarımsal faaliyetlerle sağlamaktaydılar. Mali zorluklardan muzdarip aileler, çözümü iç göçte buldular. Memleketine en yakın kasaba ve şehirlere giden gurbetçiler, kamu görevlisi, amele, çırak, kalfa gibi çeşitli görevlerde çalıștılar. Gurbetçiler gelecekte kendi işlerini bile kurabildiler. İç göçün bir diğer nedeni ise eğitimdi. Memleketinden ayrılanlar, yakındaki bir kasabaya, şehre veya İstanbul'daki medreseye gittiler. Bu makalede, iç göç hareketleri yabancı nüfus defterlerine göre tespit edilip, değerlendirilmektedir.

Anahtar sözcükler: İç göç, Üsküp, Nüfus

\section{ABSTRACT}

Domestic migration refers to the temporary or permanent process of people travelling from one place to another within the borders of the same country. People living in Skopje and its hinterland provided for their livelihood by means of agricultural activities. Families suffering from financial difficulties found that one solution to this problem was domestic migration. Migrants who went to the towns and cities closest to their hometown worked in various positions such as public servants, laborers, apprentices, or journeymen. Some of these people were even able to open their own businesses at a later date. The another reason for domestic migration was education. Those who left their hometown went to a nearby town and city or madrasah in Istanbul. In this article, the movements of domestic migration are described and evaluated based on foreign population notebooks.

Keywords: Domestic migration, Skopje, Population 


\section{Giriş}

Göç bir kişinin çeşitli sebeplerle bulunduğu mekânı süreli veya süresiz terk edip bir diğer yerde yaşaması hadisesidir. Sebebine, sayısına, gidilen yere göre gruplandırılmaktadır. Yer değişikliği ülke sınırları aşılarak yapıldığında dışa göç, ülke sınırları dahilinde gerçekleştirildiğinde iç göç olarak tanımlanmaktadır. Osmanlı bürokratı evinden barkından bir daha geri dönmemek üzere ayrılanların fiilini ev göçü veya terk-i vatan, ekonomik sebeplerle geçici olarak terk edenleri gurbetçi olarak tanımlamıştır. Çalıştığı mekânı sıklıkla değiştirenler ise gezginci olarak isimlendirilmiştir. Tarımsal faaliyetlerin yapılmadığı kış aylarında kasaba ve şehirlere gidip rızkını temin edenler, hasat vakti komşularıyla birlikte mücavir alanda veya daha uzak çiftliklerde çalışanlar, ticari maksatla gidenler, çıraklık ve kalfalık yapmak suretiyle zanaatkârlık dünyasına adım atmaya çalışan veya atanlar, kapı halkı olarak istihdam imkânı bulanlar bu gruba girerler.

Osmanlı coğrafyasında iç göç olgusu çok fazla ele alınıp incelenmemiştir. Bununla beraber bazı akademisyenler klasik döneme ait tapu tahrir kayıtlarına istinaden birtakım değerlendirmeler yapabilmişlerdir ${ }^{1}$. 1830'lardan itibaren tanzim edilmeye başlanan nüfus, yoklama ve temettü defterleri iç göçlerle ilgi oldukça detaylı veriler içermektedir. Nüfus sayımını yapan ve defterleri tanzim eden komisyonların bir kısmı sayımın gerçekleştirildiği yerlerde yerli nüfus ile yabancı nüfusu ayrı ayrı sayarak kayıt altına almıştır. Üsküp, Koçana, Kırçova, Kratova, İştip, Radovişte, Köprülü, Köstendil, Kalkandelen, Palanka, Kumanova, İvranye kasaba ve kazalarında gerçekleştirilen sayımlarda yerli olmayan nüfus için "yabancı müslim nüfus", "yabancl reaya nüfusu", "mahall-i aharda bulunanlar", "diyar-l ahara gidenler" ismiyle ayrı ayrı nüfus defterleri tanzim edilmiştir. Bu defterlerden hareketle Kosova bölgesinin 1800-1840 yılları arası nüfus göçü hakkında birtakım tespitlerde bulunmak mümkündür. Bu defterler 1831-1839 yılları arasında tanzim edilmiş ve nüfus hareketliliği 1851 yılına kadar üzerlerine kaydedilmiştir. Bölgede gerçekleştirilen nüfus sayımlarında Asakir-i Nizamiye mensubu albay, binbaşı rütbesindeki subayların riyasetinde nüfus defteri nazırı ve sairlerinden oluşan komisyon üyeleri, görev alanları dahilindeki kasaba ve köyleri tek tek dolaşarak kişilerin ismi, yaşı, eşkali, mesleği, gittiği yeri kayıt altına almışlardır. $\mathrm{Bu}$ komisyonların tanzim ettiği defterler kaza naibi ve kaza müdürü azalarından oluşan meclislerce onaylanmıştır. Bu çalışmanın ana kaynağını kaynakçada isimleri açık bir şekilde yazılan nüfus defterleri oluşturmaktadır. Çalışmanın mekânsal sınırları söz konusu defterlerin kapsadığı Üsküp, Kıratova, Kumanova, İştip, Köstendil, Radovişte, Koçana, Kırçova, Köprülü, Kalkandelen, Palanka ve İvranye kazaları ile sınırlandırılmıştır. Makalenin amacı yabancı nüfus defterlerinden hareketle belirlenen sahada 1830'lu yıllarda meydana gelen iç göç hareketliliğini tespit edip değerlendirmektir.

1 İlker Yiğit, “Anadolu Kırsalında Göçün Dünkü (16- 20. Yüzyıllar) Yapısı: Manisa ve Konya Çevresi Üzerinden Bir Göç Okuma Denemesi”, Erdem, sayı 76 (Haziran 2019), s. 205-244. 


\section{Üsküp}

1833'de Üsküp kazasının nüfusu 9.660'1 Müslim, 11.700'ü reaya ve 900'ü Çingene olmak üzere toplam 21.260 erkektir $^{2}$. Kadın ve erkeklerin eşit olduğu varsayımından hareket edecek olursak kaza nüfusunun 42.500'ü aştığını söyleyebiliriz. 1844 temettü kayıtlarına göre Üsküp kasabasının mahalle sayısı 29'u Müslim, 3'ü gayrimüslim, 1'i Yahudi, 12'si karma olmak üzere toplam 46'dır. Şehirde 1.438'i Müslim, 779'u Hıristiyan, 62'si Yahudi, 93'ü Müslüman Kıpti, 19'u gayrimüslim Kipti olmak üzere toplam 2.391 hane mevcuttur. Mevcut hane sayısından hareketle Ahmet Hamdi Furat şehrin nüfusunun 9 bin ile 9.500 arasında değiştiğini tahmin etmektedir ${ }^{3}$. Ekonomik açıdan en varlıklılar çiftlik sahipleridir. Şehir halkının büyük bir kesimi zanaatkârdır ${ }^{4}$. Hane reislerinin meslekleri dikkate alındığında şehir halkının 449'u memur, 387'si çiftçi, 210'u işçi, 1.148'inin zanaatkâr ve tüccar olduğu görülür. Çiftliktekileri temettüat kayıtlarına göre çiftlik sahibi, çiftçi, bahçıvan, çiftlik kahyası, bostancı şeklinde tasnif edebiliriz. İşçi grubunu ise temettüat kayıtlarına istinaden tebaa, çapacı, adi hizmetkâr, seyis, ırgat, tellak, natır, saraydar, çoban, hademe, hamal, hizmetkâr ve işçi şeklinde sıralamak mümkündür ${ }^{5}$. Şehir ve kırsal alanda amelmande, çolak, firari, fukara, meczup, sabi, dilenci, serseri, yetim olarak tasnif edilen işsiz grup da mevcuttu' ${ }^{6} .1844$ temettüat verilerine göre şehir çalışanlarının \%48.05'i tüccar ve zanaatkâr, \%18.79'u kamu görevlisi, \%16'sı çiftçi, \%8.9'u işçidir. \%8.16'sının mesleği ise belirtilmemiştir?

Resmî kayıtlara göre çalışma sahasında yer alan yerleşmelere yönelik göç olduğu gibi bu yerleşmelerden de başka yerlere bekar veya ailece gidenler olmuştur. Üsküp şehri bağlı kasaba ve köylerden eğitim amaçlı nüfus göçü almıştır. Nüfus defterlerine göre şehirdeki mektep ve medreselere toplam 13 kişi gelip yerleşmiştir. Gazi Muhtar Paşa Camii civarındaki mektebe Kalkandelen ve Debreli 18 ve 17 yaşlarında iki kişi gelmiştir. Gazi İsa Bey, İshakiye ve Mehmet Paşa medreselerine ise Kalkandelen, İvranye, Prizren ve Debre-i Bala'ya tâbi köylerden yaşları 14 ile 40 arasında değişen 9 kişi gelip yerleşmiştir. Gelenlerden birinin beraberinde 5 yaşında erkek kardeşi de bulunmaktaydı. Muhtemelen bu da medreseye kaydolmuştur. Söz konusu kişilerin ikamet süreleri nüfus defterlerindeki kayıtlardan anlaşıldığı kadarıyla bir ay ile on yıl arasında değişmektedir ${ }^{8}$.

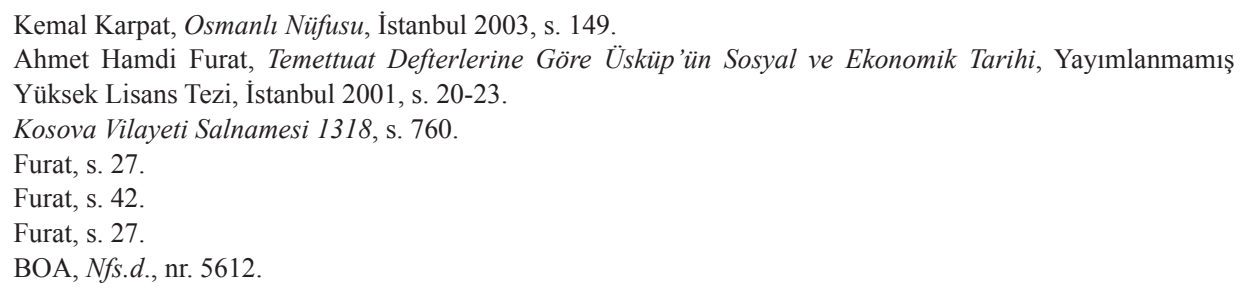


Şehrin bir diğer nüfus çekme sebebi kamu görevlisi istihdamıdır . Tanzimat öncesi Osmanlı sisteminde birçok kamu görevlisi vazifesini kapı halkı vasıtasıyla yerine getirmekteydi. Özellikle kaza, sancak ve vilayetin mülkî yetkilileri ve askerî makam sahiplerinin istihdam ettikleri görevliler ikinci bir yerleşmeden gelmekteydi. Üsküp Nazırı Mustafa Paşa'nın refakatinde Debre, Mostar, Kalkandelen ve Üsküplü 8'i yetişkin, 18 'i yaşlı olmak üzere toplam 26 kişi vardı. 5624 numaralı icmal nüfus defterine göre Üsküp’teki kale dahilinde 7 saraydaran, 10 sekban neferi, misafirhanede tüfekçi başının maiyetinde 11 sekban neferi bulunmaktaydi ${ }^{10}$.

Osmanlı kırsalında yaşayan halkın en önemli geçim kaynağı tarım ve hayvancılıktı. Halkın bir kısmı mülkiyetine veya tasarruf hakkına sahip olduğu toprağı ekip biçiyor ve geçimini temin ediyordu. Ortakçılık ve yarıcılık suretiyle çiftçilik yapanlar da vardı. Bir kısmı ise ikamet ettiği köyde veya çevre köy ve çiftliklerde çapacılık, 1rgatlık, rençperlik yapmak suretiyle hayatını idame ettirmekteydi. Harman vakitleri kitlesel boyutta işçi göçü veya mevsimlik göç olarak tanımlanabilecek olan nüfus hareketleri meydana gelmekteydi. Özellikle genç erkekler eğitim ve çıraklık maksadıyla ilk etapta çevredeki kasaba veya şehirlere gidiyorlardı. Şehirdeki gurbetçilerin bir kısmı ustaların yanına çırak olarak girip zanaatkâr olmaya çalışmaktaydı. Tercih edilen mesleklerden birisi terzilikti. Üsküp'e Debre-i zir ve bala, Kalkandelen, İvranye ve Mora'dan gelen ve şehirde terzi, terzi kalfası veya çıraklığ yapanların yaşları geliş tarihleri itibarıyla 7 ile 32 arasında değişmektedir. Gurbetçi terzilerin yaş ortalaması 15'dir. Bunların bir kısmı şehirdeki Şeyh Emin Efendi, Şeyh Hazinedar, Şeyh Bekir Efendi, Şeyh Mehmet ve Şeyh Ataullah tekkelerinde ikamet etmekteydiler. Diğerleri ise çeşitli mahallelerde yerli ahaliye ait meskenlere yerleşmişlerdir. Gurbetçilerin bir kısmı da Zübeyr, Yaşar, Şaban ve Behram isimli terzilerin yanında veya hanesinde olduğu kayıtlıdır. Muhtemelen yanlarında çalıştıkları terzilerin evinde kalmaktaydılar. 1844 tarihli temettüat defterine göre şehirde yabancı olarak Debre, Kalkandelen, Prizren ve Üsküp'ün kırsalından gelen terzi ve terzi kalfası statüsünde çalışanlar vardı. Bunlar şehirde Emin Efendi, Şeyh Hazinedar, Meddah tekkeleri ile Gazi Ali Paşa medresesinde barınmaktaydılar. Bunların kasabada bulunuş süreleri 7 ile 19 yıl arasında değişmekteydi. Belirtmek gerekirse terziler 800, kalfalar ise 200 ile 300 kuruş arasında değişen temettü vergisine tâbi tutulmuşlardır. Kasabada tüccar olarak Elbasanlı bir kişi görünmektedir. Suluhan'da ikamet eden söz konusu tüccarın temettü vergisi iki bin kuruş idi ${ }^{11}$.

Nüfus defterlerinde kasaba dahilinde abacı esnafı arasında yabancı nüfus tespit edilmezken 1844 temettü kayıtlarına göre kasaba dahilinde Üsküp, Priştine ve Koçanik'in

9 Kasaba dahilindeki kamu görevlilerini cabi, hatip, hakim, imam, kayyum, mektep hocası, müderris, müezzin, mütevelli, müezzin vekili, papaz, postnişin, şeyh, türbedar, zaviyedar, bekçi, ashab-1 alaka, katip, kocabaş1, köy kahyası, muhtar, muhzır, mültezim, münadi, naip, prangabent, sekban, mecnun, sipahi, tımarlı sipahi, yazıc1 şeklinde sıralamak mümkündür. Furat, s. 40-41.

10 BOA, $N f$ s.d., nr. 5624; Hatice Akın Zorba, “1833 Tarihli Nüfus Defterine Göre Üsküp Kazasının Demografik Yapısı", Mediterranean Journal of Humanities, VIII/1 (2018), s. 23-40.

11 BOA, ML.VRD.TMT.d, nr. 15471. 
köylerinden gelme abacı ve abacı kalfası olarak beş yabancı mevcuttur. Bunlar Debbağ Hacı Süleyman Ağa, Murad Han ve Süleyman Bey hanında ikamet etmekteydiler. Öte yandan ustasının evinde de barınanlar bulunmaktaydı. Temettüleri 150 ile 600 kuruş arasında değişmekteydi ${ }^{12}$. Kasabadaki bir diğer zanaatkâr grubunu demirciler oluşturmaktaydı. Nüfus defterlerine göre 6, 1844 temettü kayıtlarına göre Priştina ve İvranyeli iki kişi kayıtlıdır ${ }^{13}$. Bunların yaşları geliş tarihleri itibarıyla 6 ile 44 arasında değişmektedir. Bunlardan çırak ve kalfa olduğu belirtilenler 6, 13 ve 14 yaşlarındaki üç kişi ustalarının evinde ikamet ediyorlardı. Diğer üç kişi ise şehir halkına ait meskenlere yerleşmiştir. Bunlar muhtemelen kiracı statüsündeydi. Demirci sütununda bir de berber mesleğine dahil bir kişi kaydedilmiştir. 13 yaşında Üsküp'e geldiği anlaşılan bu kişi şehirdeki Berber Yusuf'un çıraği olup onun binasında ikamet etmekteydi. Bu kayıtlardan anlaşıldığı kadarıyla 15 yaşından küçük çırak ve kalfalar ustalarının meskenlerinde ikamet etmekteydiler. Şehirde yabancı olarak kaydedilen 14 nalbant mevcuttu. Bunlar Prizren, Kalkandelen ve Priştinalıdır. Geliş tarihleri itibarı ile yaşları 6 ila 23 aralığında değişmekte olup ortalama yaş 16'dır. Bunlar da demirciler gibi Üsküp'ün mahallelerinde muhtemelen kiraladıkları meskenlerde veya yanlarında çalıştıkları ustalarının evlerinde ikamet ediyorlardı.

Debbağlık Üsküp’te bir zamanlar bir hayli yaygın ve ünlü bir iş koluydu. Alaca, Meddah Camii ve Vardar sahillerinde birçok debbağhane mevcuttu ${ }^{14}$. İlgili nüfus defterlerinde 16 debbağın kaydı bulunmaktadır. Bunların Üsküp'e geliş itibarı ile yaşları 7 ila 40 arasında değişmekte olup ortalama yaş 17'dir. Bunlar Priştine, Prizren, Kalkandelen, Tikveş, Debre-i Bala kazalarına tâbi köylerden gelmişlerdir. Bunlardan üçü Meddah Debbağhanesi'nde, sekizi de Alaca Debbağhanesi'nde ikamet etmekteydi ${ }^{15}$. Bu tespitten de anlaşılacağı üzere diğer meslek grubundan farklı olarak debbağlar çalıştıkları debbağhanelerde barınmaktaydılar. 1844 tarihli temettü kayıtlarına göre Kaçanik, Pirlepe, Priştine ve Kalkandelen nüfusuna kayıtlı 6 debbağ bulunmaktadır. Bunların şehirdeki ikamet süreleri 4 ile 20 yıl arasında değişmektedir. Hepsi çalıştıkları yerlerde ikamet ediyorlard $1^{16}$.

Şehirdeki yabancı nüfusa kayıtlı tüfekçi, boyacı ve lüleci esnafi da mevcuttu. Nüfus defterlerinde bu gruba dahil 16 kişi mevcut olup bunlar Debre-i Bala, İvranye, Mat, Prizren ve Kalkandelen kazasına tâbi kasaba ve köylerden gelmişlerdi. Bunların bir kısmı oğlu ve kardeşi ile gelirken bir kısmı da bekar olduğu halde gurbet yoluna çıkmıştır. 1844'de şehirdeki yabancı tüfek ustası ve kalfası olarak Üsküp ve Kalkandelen'in köylerinden gelmiş olan 5 kişi bulunmaktaydı. Bunların şehirdeki ikamet süreleri 4 ile 20 yıl arasında değişmekteydi. Söz konusu gurbetçiler Üsküp’te Şeyh Mehmet, Dükkâncık, Şeyh Osman Tekkeleri, Molla

12 BOA, ML.VRD.TMT.d, nr. 15471.

13 BOA, ML.VRD.TMT.d, nr. 15471.

14 Kosova Vilayeti Salnamesi 1318, s. 345.

15 BOA, $N f$ s.d, nr. 5612.

16 BOA, ML.VRD.TMT.d, nr. 15471. 
Abbas Hanı, Yoğurtçular Cami-i Şerifi Mektebi binasının yanı sıra çeşitli mahallelerde kiraladıkları veya yanında çalıştıkları ustanın evinde yalnız veya oğlu ile birlikte ikamet etmekteydiler. 1844'de ise şehirde yabancı statüsünde 4 boyacı kalfası mevcuttu. Bunların Üsküp'teki ikamet süreleri 3 ile 15 yıl arasında değişmekteydi. Bunlar mektep, tekke veya ustasının evinde barınma ihtiyacını karşılamaktaydı. Temettüleri 300 ile 500 kuruş arasında değişmekteydi ${ }^{17}$. Keza 1844 tarihli temettüat kayıtlarına göre kasabadaki yabancı esnaf arasında nalbantlar da bulunmaktaydı. Şehirde Priştine, Kalkandelen ve Üsküp'ün kırsalından gelmiş olan 12 nalbant ve nalbant kalfası ikamet etmekteydi. Bunların şehre geliş süreleri 2 ila 14 yıl arasında değişmekteydi. Söz konusu nalbantlar şehirde mevcut han ve tekkeler ile kiraladıkları evlerde veya ustasının yanında ikamet etmekteydiler.

1844 temettü kayıtlarına göre kasabada 20 bozacı vardı. Bunlar kiraladıkları dükkânlarda ortağıyla veya müstakil olarak boza ve helva ticareti yapmaktaydılar. Bunların şehirdeki ikamet süreleri 3 ile 25 yıl arasında, temettü vergileri ise 150 ile 400 kuruş arasında değişmekteydi ${ }^{18}$. Aynı tarihte Debre'nin aynı köyünden gelme on dülger mevcuttu. Kasabada ikamet süreleri 6 ila 12 yıl arasında değişmekteydi. Bunlar dükkân veya hanlarda barınmaktaydılar ${ }^{19}$. Üsküp yabancı nüfus defterlerinde kahveci esnafi ile ilgili 5 kayıt mevcuttur. Kahveci esnafı Mora, Kumanova, Edirne, Kızanlık ve Prizren'den 5 ila 25 yıl aralığında gelmişlerdi. Kahveci esnafından biri Şeyh Bedreddin Tekkesi'nde diğerleri sahibi oldukları veya çalıştıkları kahvehanelerde ikamet ediyorlardi ${ }^{20}$.

Üsküp'e gelen gurbetçiler mahallelerde ${ }^{21}$ mevcut tekke, zaviye ve medreselerde veya yerli ahaliye ait meskenlerde ikamet etmişlerdir. Meskenlere yerleşenleri ustasının meskeninde ikamet edenler veya kiraladıkları evlerde oturanlar şeklinde iki gruba ayırabiliriz. Üsküp'e gurbetçilerin yanı sıra İstanbul, Debre, Priştina, Kırçova, Debre-i Bala, Prizren, Kalkandelen ve Köstendil'den ${ }^{22}$ aileleriyle birlikte gelip ileri gelenlerin yanlarına veya kiraladıkları meskenlere yerleşenler de olmuştur.

Kasabada 165'i Hristiyan, 3'ü Yahudi ve 87'si Müslim olmak üzere toplam 255 yabanc1 statüde erkek nüfus mevcuttu. Bunlardan 33 gayrimüslim kasaba dahilindeki mahallelerde ikamet ediyordu. Diğerleri çarşıda esnaf ve zanaatkârdı. Bunların mesleklere göre dağılımı şöyle idi: Birer urgancı, doğramacı, mumcu, 13 meyhaneci, 10 kuyumcu, 13 terzi, 14 semerci, 4 muytap, 10 kürkçü, 6 kasap, 26 ekmekçi, 16 simitçi. Şehirdeki Alibey hanında

17 BOA, ML.VRD.TMT.d, nr. 15471.

18 BOA, ML.VRD.TMT.d, nr. 15471.

19 BOA, ML.VRD.TMT.d, nr. 15471.

20 BOA, $N f$ s.d, nr. 5612.

21 Camii Atik, Cedid İsa Bey, Debbağ Şahin, Emir Hoca, Hacı Balaban, Hacı Hayreddin, Hacı Kasım, Hacı Muhiddin, Hacı Taceddin, Hatuncuklar, Hazinedar İsmail, Hoca Şemsi, Hüdaverdi, İbn-i muhtesip, İbn-i Payko, İbn-i Ömer, İskendergazi, İslahiye, Menteş, Haraccı Selahaddin, Muhiddin Çelebi, Kara Kapucu, Kasım Gazi, Katip Şahin, Kebir Mehmet Çelebi, Muradiye ve Yiğitpaşa.

22 BOA, $N f$ s.d, nr. 5612. 
20, kale içinde 6 ve şehrin 7 mahallesinde toplam 24 yabancı reaya vardı. Ayrıca şehirde 3 yabancı Yahudi de bulunmaktaydı. Menzilhanedeki Kıptilerin sayısı ise 2'si Hristiyan, 18'i Müslim olmak üzere toplam 20 kişiydi. Gurbetçi Müslümanların dağılımı ise şu şekildeydi: Ibn-i Payko mahallesi Şeyh Mehmet Efendi Tekkesi'nde 7, Hacı Taceddin mahallesinde vaki hamamda 4, Alaca Medresede 4 ve kala içinde 25, misafir konağında 14 olmak üzere 54 kişi. Ayrıca 33 kişi de kamuda görevli idi²3.

Üsküp kazasına tâbi köyler dört gruba ayrılarak sayım yapılmış ve buna göre deftere kaydedilmiştir. Birinci grup Çayırova koludur. Üsküp şehrinin kuzeydoğusuna isabet eden güzergâhta toplam 56 köy mevcuttu. Bu güzergâhtaki köylerin toplam nüfusu yabancı nüfus dahil olduğu halde 6.011 erkektir. Bunun \%17.46's1 Müslim, \%77.69'u Hristiyan, \%4.84'ü Kıpti nüfustur. İkinci güzergâh şehrin kuzey ve kuzey batısına uzanan Karadağ koludur. Bu güzergâhta ise 32 köy bulunmaktaydı. Bu köylerin toplam nüfusu 3.349 erkek nüfustur. Bunun \%79.57'si Hristiyan, \%19.46's1 Müslim ve \%1.25'i Kipti nüfustur. Vardar'ın güneybatısındaki bölge Karşıyaka olarak isimlendirilmiştir. Bu güzergâhta bulunan köylerin sayıs1 59'dur. Kırsal alandaki toplam nüfus 5.040 erkektir. Bunun da \%45.01'i Müslim, \%52.98'i Hristiyan ve \%1.99'u Kıpti nüfustur. Dördüncü güzergâhta 1.252 erkek nüfusun yaşadığ 8 köy yer almaktaydı. \%98'i Müslimdir ${ }^{24}$. Bu köylerin 6'sında 17 yabancı Müslim ve 42'sinde ise 147 yabancı reaya erkek nüfus vardı. Netice itibarıyla 1833'te Üsküp kazası dahilinde toplam 22.452 erkek yaşamaktaydı. Bunun \%51.63'ü Hristiyan, \%43.71'i Müslim, $\% 4$ 'ü Kıpti nüfus idi' ${ }^{25}$.

1844 temettüat kayıtlarına göre Üsküp'e dışarıdan gelip yerleşen 125'i Müslim, 260'1 gayrimüslim olmak üzere toplam 385 kişi mevcuttu. Bunlardan 291'i yerli statüsü kazanırken arta kalanlar halihazır yabancı statüsündeydi. Yabancı statüsündeki Müslümanların 10'u Prizren, 11'i Priştina, 34'ü Debre, 19'u Üsküp köyleri, 4'ü Tepedelen ve 22'si Kalkandelen'den, diğerleri Anadolu, Edirne, Elbasan, Estorava, İvranye, Kaçanik, Dilan, Geylan, Koçana, Kumanova, Köprülü ve Ohri'den gelmişlerdir ${ }^{26}$. Gayrimüslimlerin büyük bir kesimi ise Kalkandelenlidir. Kasabaya yerleşen 320 gayrimüslim ailenin 104'ü Kalkandelen, 46'sı Kumanova, 42'si Kırçova, 18'i Manastır, 13'ü Debre, diğerleri Belenka, Bosna- Saray, İşkodra, Köprülü, Kratova, Leskofça, Mora, Ohri, Pazarcık, Palanka, Pirlepe, Priştine ve Terebin ve 50 hanesi Üsküp'ün köylerinden göç etmiştir ${ }^{27}$. Kırsal alandan nüfus çeken kurumlardan birisi de zaviyelerdir. Örneğin Hızır Baba zaviyesinde Şehirköy, Kalkandelen, Hayrabolu ve Pirlepeli 4 kişi mevcuttu ${ }^{28}$.

23 BOA, $N f$ s.d, nr. 5624; Zorba, a.g.m., s. 23-40.

24 BOA, $N f s . d$, nr. 5624; Zorba, a.g.m., s. 23-40.

25 BOA, Nfs.d, nr. 5624; Zorba, a.g.m., s. 23-40.

26 Emine Gül, 19. Yüzyılda Makedonya ve Üsküp Kazası, Yayınlanmış Yüksek Lisans Tezi, İstanbul 1999, s. 34.

27 Gül, a.g.e., s. 34- 35.

28 BOA, $N f$ s.d, nr. 5612. 
Üsküp kasabası ve köylerinden dışa yönelik göç ile ilgili 5613 numaralı nüfus defterinde oldukça detaylı bilgilere ulaşmak mümkün gözükmektedir. Bu deftere göre Tuna sahilleri, Kumanova, Belgrat, Diyarbakır, Manastır, Ohri, Köstendil, İvranye, Kratova, Kırçova, Mısır, Hicaz, Niş, Berkofça, Bosna, Köprülü, İstanbul, Karasuyenice, Travnik, Ustrumca, Edirne, Siroz, Debre-i Bala ve Kalkandelen'e çeşitli sebeplerle gidenler olmuştur. Deftere göre kasabadan ayrılanlardan 37'si yetişkin, 3'ü çocuk, 33'ü yaşlı olup, 3'ü de Asakir-i Mansure-i Muhammediye'ye iltihak etmişlerdi. Köylerden göç edenler 72 kişidir. Dişa göçün bir sebebi herhangi bir suçtan dolayı aranan zanlıların firar etmesidir. Çeşitli sebeplerle suç işleyenler kanuni takibattan kurtulabilmek adına firar edebilmekteydiler. Bu gibilerin amacı izlerini kaybettirmek ve herhangi bir cezaya çarptırılmamaktı. Yapılan soruşturmalarda bu gibilerin isimlerinin geçtiği yere cünha olup firar ettiği ve bulunduğu yerin bilinmediği kaydı düşülmekteydi. Aklına hiffet getirip memleketini terk edenler de oluyordu. Kasaba ve kazayı terk edenler arasında ırgatlık, hizmetkârlık, zanaatkârlık gibi iş kollarında iş bulup çalışmayı hedefleyenler çoğunluktaydı. Örneğin, Üsküp'ün bir köyünden ayrılan 11 kişi İstanbul'da Yenikap1, Küçük Karaman, Langa, Silivrikap1, Davutpaşa iskelesi ve Topkapı'daki fırınlarda istihdam alanı bulmuştur. Başta İstanbul olmak üzere çevre kasabalara "serseri" tanımlamasıyla gidenler de olmuştur. Ticari faaliyette bulunmak amacıyla geçici olarak gidenler de vardı. Bu tür gidenler diğerlerine göre daha fazlaydı. Bir diğer göç sebebi eğitim idi. Yukarıdaki açıklamalardan anlaşılacağı üzere Üsküp eğitim sebepli göç alırken aynı gerekçeyle Üsküp kasaba ve köylerinden başka yerlere gidenler de olmuştur. Klasik dönem Osmanlısında babanın sahip olduğu kamusal imtiyaz ve yükümlülük gerekli şartları haiz olmak şartıyla çocuklarından birine intikal edebiliyordu. Örneğin Üsküp’te Timarlı sipahinin çocuğu babasına bedel olarak gerekli yükümlülüğü yerine getirebilmek adına kazadan ayrılmıştır. Üsküp kasaba ve köylerinden hane nakli de gerçekleşmiştir. Söz konusu hane göçlerinin oluş gerekçeleri defterlerde kayıtlı değildir. Mekanı geçici olarak terk etmenin diğer sebebi kamusal alanda görev almak, haç farizasını yerine getirme faaliyetidir.

7 Mayıs 1838 tarihli 5614 numaralı nüfus defterinde Üsküp kasabasından dışarıya giden reayaya ait bilgiler mevcuttur. Bu kayıtlara göre 35 gayrimüslim ticari faaliyetlerde bulunmak, Hristiyan din adamlarına hizmet etmek, büyük şehirlerde iş bulup çalışmak veya herhangi bir amacı olmaksızın belgenin tanımlamasıyla "serseri” olarak Kalkandelen, Belgrat, Siroz, Saray, Debre-i Bala, İpek, İstanbul ve Prizren’e gitmiştir. Üsküp’ü terk edenlerden beşi din adamı veya din adamlarına hizmet eden kişilerdir. Bunlardan birisi Üsküp Metropoliti’ydi. Söz konusu kişi 6 yıl önce Paşalimanı'ndan gelmiş olup 1838 yılında İstanbul'a gitti. Metropolitle birlikte İstanbul'a gelen bir diğer kişi de yine işi gereği iki aylığına İvranye kazasına gitmişti. Bir başka kişi ise Manastır'daki keşişlerin hizmetine girmek için İpek’e giderken, bir diğeri Debre-i Bala'nın köyündeki kilisede istihdam alanı buldu. Defter tanzim edildiği esnada kayıtlı olan kişilerin gidiş süreleri 4 ay ile 8 sene arasında değişmekteydi ${ }^{29}$.

29 BOA, $N f$ s.d, nr. 5614. 
20 Mayıs 1838 tarihli nüfus defterine göre Üsküp kırsalından başka yerleşmelere giden gayrimüslim erkek nüfus toplam 159 kişidir. Yazımın gerçekleştirildiği tarih itibarıyla bu kişilerin yaşları 5 ila 95 arasında değişmekte olup ortalama yaş 31.32'dir. Cizye mükellefiyetlerine göre 3'ü ala, 94'ü evsat, 36's1 edna statüsünde iken 14'ü küçük, 2'si ise amelmandedir. $\mathrm{Bu}$ verilere göre yerini terk eden erkek nüfusun \%71'inin ekonomik açıdan orta gelir grubunda olduğunu ifade edebiliriz. 6 kişi memleketini terk ederek başka bir diyara gitmiştir. Bunların gidiş sebepleri ve gittikleri yer yazım esnasında yapılan sorgulamada tespit edilememiştir. 33 kişi ikametgâhını Üsküp'ün başka bir köyüne taşırken, 37 kişi ise mâaile Pirlepe, Kalkandelen, Köprülü ve Paşa sancağı dahilindeki yerleşmelere göç etmişlerdir. 45 erkek ise çalışmak veya resmî işlemleri takip etmek gayesiyle İstanbul'a gitmiştir. Bunlardan 25'i Kumkapı Yeni Fırın, Karagümrük Fırını, Kumkapı Nişancı Fırını, Üsküdar Hibaz Fırını, Büyük Karaman Fırını, Darphane Fırını, Langa Nişancı Fırını'na yerleşmiştir. Manastır, İvranye, Selanik, Siroz, Gümülcine, Edirne, Köprülü, Manastır ve Aynaroz Manastırı'na tedavi maksatlı gidenler olmuştur. Gerekçesiz olarak yerini yurdunu terk edenler de vardı. Resmî makamlar bu gibileri "serseri” olarak tanımlamıştır. Belgenin "serseri” olarak tanımladığı dokuz kişi Yanya, İstanbul, Pirlepe, Tikveş ve Vidin'e gitmişlerdi.

\section{İştip}

İştip kasabası Üsküp'e 70 km. uzaklıktadır. İştip arazisi dört kola ayrılmaktaydı. Kaza halkı Müslim, Bulgar, Kıpti ve Yahudilerden oluşmaktaydı. Ami Boue'nin tahminine göre kazanın nüfusu 1836'da 15-20 bin kişi arasında değişmekteydi. Aynı tarihlerde kazanın merkezi İştip kasabasının nüfusu dört bin civarındaydi ${ }^{30}$. Kazanın Veniçe, Yörükhan, Lıkavişe ahalisi İştip, Okçepol kolu dahilindeki köylüleri alışverişlerini Köprülü ve Bereketli nahiyesinin merkezi Kilisalı kasabasında ${ }^{31}$ yapıyorlardı. Çiftçilikle geçimini temin eden kaza halkının \%8'i ırgatlık, \%3.3'ü ortakçılıkla, geri kalanı kendi arazilerini işleyerek geçimlerini temin ediyorlard $1^{32}$. Kazada ticaretle geçimini temin edenler İstanbul ve Selanik’ten getirdikleri malları İştip kasabasında pazarlamaktaydılar. Kundura, yemeni, pamuklu, muytap ve sair ticari malların fazlası Koçana, Kratova, Radovişte ve Palanka sahasina sevk edilmekteydi.

5613 numaralı nüfus defterine göre kaza merkezi İştip kasabasından 11'i yetişkin, 9'u yaşlı olmak üzere toplam 20 erkek ayrılmıştır. Bunların kasabadan ayrılış sebeplerini haç farizasını yerine getirmek, eğitimini sürdürmek ve kısmetini aramak şeklinde sıralamak mümkündür. Bunlar Vidin, Lom, Kavala, Debre, Hicaz ve İstanbul'a gitmiştir. İştip'e tâbi köylerden 34'ü yetişkin, 8'i sıbyan, 8'i yaşlı olmak üzere toplam 50 kişi genellikle Pravadi, Debre, Lom,

30 Machiel Kiel, "İştip”, DİA, c. XXIII, İstanbul 2001, s. 440-442.

31 Kosova Vilayeti Salnamesi 1318, s. 370-318.

32 Kosova Vilayeti Salnamesi 1318, s. 370. 
Kavala, Manastır, Kalkandelen, Tikveş, Ustrumca, Doyran, Köprülü ve Palanka gibi mücavir alandaki şehir ve kasabalara giderken, bir kısmı da Mısır, Hicaz ve İzmir gibi deniz aşırı liman ve kasabalara gitmişlerdir. Bunların ocaklarını terk ediş sebeplerini kısmet arzusu, haç farizasını yerine getirmek, sekbanlık yapmak, kavasların maiyetinde kamu hizmeti yapmak, köylerde çobanlık yapmak şeklinde sıralayabiliriz. Osmanlı bürokratlarının "serseri” olarak tanımladığ 1 işsiz ve güçsüzler de memleketlerini terk edebilmişlerdir. Yerleşmeleri terk edenler arasında sanıklar da vardı. Bunların amacı kanuni takibattan kurtulmaktı. Yapılan soruşturmalarda bunların yerleri tespit edilememiştir. Timarlı sipahilerin çocukları da ocaklarını geçici olarak terk edebilmişlerdir ${ }^{33}$.

İştipli gayrimüslim ahali de çeşitli sebeplerle daimi veya geçici statüde ocağını terk edebilmiştir. 5614 numaralı nüfus defterine göre İştip kasabasından biri çocuk olmak üzere 12 kişi, köylerden 3'ü çocuk 34 kişi ticaret yapmak, başıboş dolaşmak veya ikametgâhını taşımak amacıyla Sofya, İstanbul, Selanik, Tikveş, Belgrat ve Paşa sancağına tek başına veya ailesiyle birlikte gitmiştir. Ayrıca kazanın köylerinden kasabaya veya kasabadan tâbi köylere de gidip yerleşenler olmuştu ${ }^{34}$. Belirtmek gerekirse dişardan kasabaya gelenler de vardı. Bunlar daha ziyade kamu görevinde istihdam edilmişlerdi. Örneğin kaza müdürünün maiyetindekilerin üçü Kalkandelenlidir.

\section{İvranye}

Morava nehri vadisinde bulunmaktadır. 1831 yılına ait nüfus defterinden anlaşıldığı kadarıyla kazaya 306 köy bağlıydı ${ }^{35}$. Kaza dahilinde Kumanova, Üsküp, Palanka, Köprülü, Geylan ve Nişli toplam 289 yabancı statüsünde gayrimüslim nüfus mevcuttu. Bunlardan 105'inin mesleğini tespit etmiş bulunmaktayız. Söz konusu kişilerden 17'si hanc1, 19'u dülger, 15'i kirac1, 14'ü rençper, 18'i hizmetkâr, 4'ü terzi, ikişer kişi papaz, urgancı, çömlekçi, enfiyeci, birer kişi de hancı çırağı, bakkal, dülger çırağı, dülger kalfası, kalaycı, papuçcu, papuçcu çırağı, göncü, meyhaneci, hekim, enfiyeci ve tüccar idi. Bunlar genelde bekar olarak geliyorlardı. Bununla beraber bazılarının yanında oğlu, kardeşi, çırağı, kalfası, hizmetkârı, yeğeni ve torunu bulunmaktaydı. Yabanc1 gayrimüslimlerin 21 'i ala, 175'i evsat ve 93'ü edna statüde cizye vergisine tâbiydi. Bunlardan 61'i zamanla Yanya, Priştine, Köprülü, Debre, Pirlepe, Manastır, Yakova, Samako, Gilan, Şehirköy, Niş, Leskofça, Kumanova, Prizren, Köstendil, İşkodra'ya gitmiştir ${ }^{36}$. Ayrıca iki müslim Kıpti nüfus mevcuttu ${ }^{37}$. 


\section{Kalkandelen}

1831 sayımına göre kazanın nüfusu 11.766's1 Müslim, 8.043'ü reaya ve 472'si Kıpti ${ }^{38}$ olmak üzere 20.281 erkektir. Kadın nüfusu da dikkate alacak olursak kaza nüfusu 40 bini aşmaktadır. Kalkandelen kazasının halkı tamamen Arnavutlardan oluşmaktaydı. Kazanın kırsalında Müslüman nüfusun yaşadığı 117 köy 4 güzergâhta toplanmıştı. Yukarı kol güzergâhında 69, Derbent kolunda 13, Dedeboğazı'nda 8, Aşağıkol güzergâhında 27 köy mevcuttu. 1839'da bu köylerde toplam 9.490 Müslim erkek yaşamaktayd1. Kazadaki Müslüman erkek nüfusun toplamı 4.632'si yetişkin, 3.141'i çocuk ve 4.299'u yaşlı olmak üzere toplam 10.768 kişiydi. Ayrıca kaza dahilinde 601 redif, 52 süvari mevcuttu. Bu köylerde 137'si Müslim ve 154'i gayrimüslim olmak üzere toplam 291 Kıpti erkek mevcuttu ${ }^{39}$.

Hicri 1314 Tarihli Kosova Vilayeti Salnamesine göre kaza halkı çiftçi, tüccar ve gurbetçi olmak üzere üç gruba ayrılmaktaydı. Gurbetçiler gittikleri yerlerde ihtisas ettikleri mesleklerini kış aylarında 6 ay icra ediyor, biriktirdikleri paraları bahar ve yaz aylarında ailesiyle beraber memleketinde harcıyorlardı. Kış yaklaşınca tekrar çalışmaya gidiyorlardı. Hicri 1318 Tarihli Kosova Vilayeti Salnamesinde vurgulandığı üzere kasabadan köylerine varıncaya kadar Kalkandelenliler Memalik-i Şahane'nin gezmedik bir mahallini bırakmadıkları gibi yurt dışına da gitmekteydiler. Bölgede tüfek imalatı ve terzilik pek ileri seviyededir. Tüfek ustaları herhangi bir eğitimden geçmemelerine rağmen bir kez gördükleri modeli kolaylıkla taklit edebilmekteydiler. Patent uygulaması sonrası taklit yasaklanınca bölgede tüfek imalatı durdu ${ }^{40}$. Tüfenkhane-i Amire ihtiyaç duyduğu kundakçı, çakmakçı ve çakıcı ustalarını uzun bir süre Prizren ve Kalkandelen'den karşılamıştır ${ }^{41}$.

1839 yılında tanzim edilen 5623 numaralı nüfus icmal defterinden anlaşıldığı kadarıyla Kalkandelen kasabası 8 mahalleden oluşmaktaydı. Kasaba dahilinde 92 redif, 42 süvari ve 1.797 Müslüman erkek bulunmaktaydı. Ayrıca kasaba dahilinde 85'i Müslim ve 5'i gayrimüslim olmak üzere Kıpti erkek de mevcuttu. Kalkandelen kasabasında Paşa, Garciyan, Molla Abbas, Topalzade Mehmet Ağa, Elhac Sadık, Süleyman Ağa ve Elhac Mehmet Ağa Hanı'nda Ohrili, Prizrenli, Manastırlı, Kırçovalı, Üsküplü, İşkodralı hancı, semerci, kürekçi, papuççu, terzi, kuyumcu ve doğramacı esnafina mensup 30 gayrimüslim müsteciren ikamet etmekte ve çalışmaktayd $1^{42}$.

38 Karpat, a.g.e., s. 149.

39 BOA, $N f s . d$, nr. 5623, Üsküp Eyaleti Üsküp Sancağı Kalkandelen Kazası, Yukarı kol, Dereboğazı, Derbent, Yukarı ve Aşağı kol mahalle ve karyelere göre icmal defteri H. 1254.

40 Kosova Vilayeti Salnamesi 1318, s. 780.

41 BOA, A.MKT.MHM, 6/56 (H. 1264), 8/59 (H. 1265).

42 BOA, Nfs.d, nr. 5574, Kalkandelen Kaza ve Kasabasında Bulunan Yabancı Zımmıyan Nüfus Defteri. BOA, Nfs.d, nr. 5576 numaralı deftere göre Topalzade Mehmet Hanında 7, Molla Abbas Hanında 53 kişi ikamet ediyor. 
Aynı nüfus defterinden anlaşıldığı kadarıyla kasaba dahilinde "enfiye deyneklerinde" Prizrenli üç kişi müsteciren bulunmaktaydı. Ayrıca kasaba ve mücavir alanındaki bahçelerde istihdam edilen üç bahçıvan mevcuttu. Bunlardan birinin beraberinde bir de hizmetkârı vardı. Kasaba dahilindeki meyhanelerde Manastır ve Delvineli üç meyhaneci mevcuttu. Keza Kalkandelen kazasının köylerinde Manastır ve Kırçovalı üç yabancı zımmi nüfus mevcuttu ${ }^{43}$.

\section{Kırçova}

Kırçova kazası 1831 sayımına göre 2.286'sı Müslim, 5.154'ü reaya ve 88'i Kıpti olmak üzere toplam 8.328 erkek nüfusun yaşadığ 1 bir idari birimdi ${ }^{44}$. Balkan kolu tabir olunan 2530 köy müstesna kaffe arazisinde çeltik ziraatı yapılmaktaydı. Elde edilen mahsul eyaletin her köşesinde satılmaktaydı. Özellikle pirinç ticareti bir hayli yaygınd1 ${ }^{45}$. Kırçova'daki yabancı nüfus daha ziyade kamu görevlisidir. 1845 yılında Kırçova kazasının müdürü Manastır vücuhundandır. Kaza müdürünün hizmetinde istihdam edilen kişilerden beşi Manastır, Yanya, Tepedelen, Ergere ve Prizrenlidir. Kırçova kalesi muhafızı da Prizrenliydi. Muhafızın maiyetinde Debre, Üsküp, Prizren, Florina, Ohri, Manastır ve Pirlepeli 23 kişi vardı. Bunların yaş ortalaması 31 idi. Kırçova Buyuyan Çiftliği çalışanları arasında Debre kasabasından 7 kişi, Üsküp kasabası İbn-i Şahin ve Hüdaverdi mahallelerinden 8 kişi ve Üsküp ile Kalkandelen'in köylerinden 3 kişi, Kratova kasabasından beş kişi bulunmaktaydı ${ }^{46}$.

5583 numaralı nüfus defterine göre Kırçova kasabası ve kırsalında tüccar ve misafir statüsünde 79 kişi bulunuyordu. Bunların bir kısmının mesleği belirtilmemiştir. Mesleği belli olanlardan birer kişi boyacı, hancı, mübayaacı ve 9 kişi terzilik yapmaktaydı. Terzilerin hepsi Manastır kazasının Kurşuh köyünden gelmiştir. Bunlardan 6'sının beraberinde ikişer çırağ 1 vardı. Mesleği belli olmayanlar arasında 31 kişi Köstendil kazasının aynı köyüne mensuptu. Manastır ve Radomirli olanlar da vard1 ${ }^{47}$.

1842 yılına ait kayda göre 22 Kırçovalı Müslim erkek kaza sınırlarını terk etmiştir. Bunlardan dördü Kırçova kasabasından gurbetçi statüsünde ayrılmıştır. Kırsaldan göç eden 18 kişiden 7'si ticaret ve sair sebeplerle geçici olarak memleketini terk ederken 11'i ailesiyle göç etmiş ve bunlar Kalkandelen, Selanik, Manastır, Vidin, Edirne ve Üsküp'ün köylerine gidip yerleşmişlerdir ${ }^{48}$. 5613 numaralı defterde söz konusu nüfus hareketleri sair defterlerden farklı olarak göç kavramıyla tanımlanırken, gurbetçi statüsünde olanların geri dönüş tarihleri de sorgulanmıştır. Alınan cevaplar deftere kaydedilmiştir ${ }^{49}$. Kırçova kasabasından 9,

43 BOA, Nfs.d, nr. 5574.

44 Karpat, a.g.e., s. 149.

45 Kosova Vilayeti Salnamesi 1318, s. 477.

46 BOA, $N f s . d$, nr. 5580, Kırçova kazasında Berayı ticaret misafireten ikamet üzere bulunan yabancı ehl-i İslam (1262).

47 BOA, Nfs.d, nr. 5583.

48 BOA, Nfs.d, nr. 5613.

49 BOA, Nfs.d, nr. 5613. 
köylerinden 223 gayrimüslim ticaret, serseri, naklhane statüsünde İstanbul, Manastır, Vidin, Karaferye, Elbasan, Selanik, Üsküp, Belgrat, Kalkandelen, Niş kasabası veya köylerine gitmişlerdir. Kırçovalı gurbetçiler daha çok Vidin'e gitmişlerdir ${ }^{50}$.

\section{Koçana}

Koçana kasabasının temelinin antik çağda atıldığı anlaşılmaktadır. Koçana 65 köyün tâbi olduğu bir kaza merkezidir. Kaza dahilinde 1831'de 3.374'ü Müslim, 6.112'si gayrimüslim olmak üzere toplam 9.486 erkek nüfus mevcuttu ${ }^{51}$. Kadın ve erkek nüfusun eşit olması halinde kazanın toplam nüfusunun 19 bine yaklaştığını ifade edebiliriz. Kırsal yerleşmelerin bir kısmı köy bir kısmı da çiftlik statüsündedir. Kırsaldaki yerleşmeleri toplumsal açıdan Müslim, Hıristiyan ve karma olmak üzere üç gruba ayırabiliriz. Kırsaldaki ahalinin bir kısmı çiftlik sahibi olup kendi arazisini ekip dikmekteydi. Arazisi olmayanlar ortakçılık, yarıcılık, aylakçılık ${ }^{52}$ veya maden ameleliği yapmak suretiyle geçimini temin ediyordu. Bölgede haşhaş ve çeltik ziraatı bir hayli yaygındı. Ayrıca bostan ve bağ ziraatı da yapılmaktaydı. Büyük köylerde imam, papaz, kocabaşı gibi din adamlarının yanı sıra zaim, sekban, doğancı reayası, asakir-i redif, bekçi ve türbedar gibi kamu görevi ifa edenler de vardı. Ayrıca ticaretle iştigal edenler, değirmen ve kahvehane işletenler, boyacı, nalbant ve kasap gibi esnaf da vardı. Kaza dahilindeki halkın \%56'sının gelir kaynağı kendi arazisinde ürettiği mahsuldür. \%9'u çiftlik sahibi, \%10'u tacirdi. Defterlere tüccar olarak kaydedilmiş kişilerin bir kısmı ticaret, bir kısmı ise emek gücü ile geçimini sağlıyordu. Nüfusun \%7'si adi hizmetkâr, \%7'si aylakçı (Ramazan davulcusu, pirinç bekçisi, türbedar) diğerleri esnaf ve zanaatkârdı.

Koçana kasabası 237'si Müslim ve 149’u gayrimüslim olmak üzere 386 haneden oluşmaktaydı. Kasaba dahilinde Müslüman esnaf zümresini berber kalfası, pirinç bekçisi, oduncu, kahveci, imam, müezzin, doğramac1, kasap, saraç, tüccar, bekçi, aylakçı, kethüda, hizmetkâr, bakkal, nalbant, boyacı, tüfekçi, iskeleci, duhancı, duhan kıyıcısı, hamamcı, sığırtmaç, semerci, derbentçi, oduncu, kahveci şeklinde sıralamak mümkündür. Gayrimüslimleri ise kocabaşı, dülger, terzi, taşçı, kürekçi, çoban, semerci, kasap, aylakçı, sabuncu, papaz, değirmenci, saatçi, ziraatçı, kürekçi (pirinç tarlasını hazırlayan işçi), kiracı, değirmenci, aylakçı şeklinde sıralayabiliriz.

Nüfus defterlerine yansıdığı kadarıyla Koçana kasabası ve kaza dahilindeki dokuz köye ticaret veya emek gücüyle çalışmak kastıyla gelmiş olan Debre, Manastır, Yanya, Kalkandelen, İştip, Köstendil ve Palankalı gayrimüslimler mevcuttu. Söz konusu nüfus defterlerine göre kasaba dahilinde 101 yabancı reaya mevcuttu. Bunların yaşları 8 ile 57

$50 \quad$ BOA, Nfs.d, nr. 5614.

51 Karpat, a.g.e., s. 149.

52 Gökay Karaduman, Temettuat Defterleri Çerçevesinde Koçana / Üsküp Kazasının Sosyal ve Ekonomik Yapısı, Yayımlanmamış Yüksek Lisans Tezi, İstanbul 2014. 
aralığında değişmektedir. Kayıtlı olduğu kadarıyla bunlar terzi, hancı, bozacı, dülger, taşçı, ekmekçi, hizmetçi ve dikici gibi zanaat, esnaf ve işçi sınıfına mensuptular. Bunların çoğu Koçana'ya tek başlarına gelmişlerdi. İki kişinin yanında çocukları vardı. Bazı esnaf ise gelirken beraberinde çalışanlarını da getirmişlerdi. Kasabanın yanı sıra Koçana kazasının 11 köyünde Köprülü, Kalkandelen, Yanya, Kırçova, Ereğli, Köstendil, Razlık, Maleş, İştip, Manastır, Debre, Tikveş, Kratova, Palankalı 62 kişi vardı. Köylerdeki yabancılar çobanlık, hizmetkârlık, dülgerlik, terzilik, çakıcılık, hancı ticareti, demircilik, bakkallık, simitçilik ve sabunculuk faaliyetlerinde bulunmaktaydılar. Bunlardan birisi ailesiyle gelmişti ${ }^{53}$.

Koçana kasabasında yabancı statüsünde Üsküp, Ohri, Kalkandelen ve İştipli bir çocuk, 17 yetişkin ve 21 yaşlı Müslim erkek vardı. Bunlar nalbantlık, boyacılık, çiftlik kethüdalığı ve ihtisap memurluğu ile geçimini temin ediyorlardı. Koçana’nın 4 köyünde de İştip ve Köstendilli Müslümanlar vardı. Bunlar geçimlerini hizmetkârlık ve çömlekçilikle sağliyorlard $1^{54}$.

\section{Köprülü}

Vardar vadisinde kurulmuş olan kasaba aynı isimle anılan kazanın merkezidir. Kasabada nalbant esnafi fazla miktarda mevcuttu. Kasabada her y1l 8- 10 mayıs tarihleri arasinda panayır kurulmaktaydı. Burada yün ve deriden yapılmış olan mallar pazarlanırdı. Ayrıca üzümü meşhurdu. Binlerce okka üzüm Pirlepe, Manastır, İştip, Üsküp, Kumanova ve Kalkandelen cihetlerine ihraç edilirdi ${ }^{55}$.

1831 'de Köprülü kazasının nüfusu 4.767'si Müslim, 12.718'i reaya, 390'1 Kıpti ${ }^{56}$ olmak üzere toplam 16.875 erkekten ibaretti. Bu kadar da kadın nüfusun olduğunu farz edersek kaza nüfusu 34 bini bulmaktaydı. Rum milletinden Yanya ve Manastırlı 8 kişi hancılık ticareti yapmak üzere kaza dahilinde Yenihan, Babuna Hanı, Virancıkya Han1, Bercurek Hanı, Gariçe Hanı'nda ikamet etmekteydiler. Söz konusu tacirlerden birisi oğlu ve 2 hizmetkârı ile bir diğer tacir ortağı ile birlikte bulunmaktayd $1^{57}$. Kaza müdürünün maiyetindekilerden bir kısmı Tikveş, Prizren, Yanya ve Paşasancaklı'dır.

Kazanın merkezi Köprülü kasabasından nüfus defterine göre 6'sı yetişkin ve 3'ü yaşlı olmak üzere toplam 9 Müslim erkek Mısır, Kalkandelen, Yenişehir, Selanik ve Bosna’ya gitmiştir. Bunların gidiş sebepleri ticaret veya kesin göçtür. Kazanın kırsalından ise 13’ü yetişkin, 14’ü yaşlı ve 10’u küçük olmak üzere toplam 37 Müslim kazayı terk etmişstir.

53 BOA, $N f$ s.d, nr. 5670, Nefs-i Koçana'da ve Koçan'a kazasında han bulunan köylerindeki yabancı reayanın yaş, eşkal ve zanaatları ve esamilerini mübeyyen ber-vech-i nüfus defteri.

54 BOA, Nfs.d, nr. 5669.

55 Kosova Vilayeti Salnamesi 1318, s. 410.

56 Karpat, a.g.e., s. 149.

57 BOA, $N f s . d$, nr. 5605, Köprülü Kazasında Bulunan Yabancı Reaya Defteri. 
Bunların 32'si aileleriyle birlikte göç etmişlerdi ${ }^{58}$. Köprülü kazası dahilindeki kasaba ve köylerinden orta gelirli 80, düşük gelirli 22 ve çocuk yaşta 6 gayrimüslim Belgrat, Pirlepe, Yenişehir, Eflak, Aynaroz, Selanik, Mora, Siroz, Tikveş, Manastır, Pazarcık, Prizren, Leskofça, İzmir, İstanbul ve Anadolu'nun sair yerleşmelerine çalışmak gayesiyle veyahut ailesi, kardeşi ve annesiyle naklhane statüsünde gitmiştir. Gidiş süreleri 6 ay ile dokuz sene arasında değişmektedir. Söz konusu kişiler ismi zikredilen kazaların köylerine daimi statüde yerleşmiştir ${ }^{59}$. Diğer nüfus defterlerinden anlaşıldığı kadarıyla Köprülü’den Üsküp, Koçana, Kumanova, İvranye, Kratova ve İştip gibi çevredeki yerleşmelere ve kazaların kırsalına da nüfus göçü gerçekleşmiştir.

\section{Köstendil}

Kazanın nüfusu 1831 sayımına göre 3.032'si müslim, 14.070'i reaya, 232'si Kıpti ve 145'i Yahudi olmak üzere toplam 17.479 erkektir $^{60}$. Kasaba dahilindeki Müslümanlar beş mahallede ikamet etmekteydi. Kasabadaki Müslüman erkeklerin 560'1 yetişkin, 457'si çocuk ve 274'ü yaşlı nüfus konumundayd1. 78 kişi amelmande statüsündeydi. Kazaya tâbi 19 köydeki Müslüman erkek nüfusun toplamı ise 584'i yetişkin, 690'1 çocuk, 457'si yaşlı olmak üzere toplam 1.731 kişiydi ${ }^{61}$.

Kazanın merkezi Köstendil kasabası Samakov, Kratova, Sofya, Ohri, Palanka, İşkodra, İştip, Yanya, Manastır, Zagor, İzladi ve Koçana’dan nüfus göçü almıştır. Kasabaya gelenlerin bir kısmı tüccardır. Tüccarlar yaptıkları işin hacmine göre tek başlarına gelebildikleri gibi beraberinde damadı, oğlu, kardeşi gibi hısım ve akrabalarını veya çalışanlarını getirenler de vardı. Bir kısmı da kasabaya tek başına gelmiş, işini büyütünce yanında işçi çalıştırmaya başlamıştı. $\mathrm{Bu}$ şekilde istihdam edilen çalışanlardan bir kısmı da yabancı statüsündedir. Kasabadaki yabancılar kuyumculuk, hancılık, terzilik, demircilik ve simitçilik yaparak geçimini temin ediyorlardı. 5694 numaralı nüfus defterinde kayıtlı olan yabancılardan 4'ü kuyumcu, 7'si hanc1 olup, birer kişi de terzi ve demircilik yaparak iaşelerini temin ediyorlard $1^{62}$. Köstendil'in bazı köylerinde de han mevcuttu. Şüphesiz bu hanlarda ikamet edenlerin hepsi yabancı statüsündeydi. Defterlere yansıdığı kadarıyla Köstendil'in köylerindeki hanlarda gayrimüslim tüccar ve zanaatkârlar vardı. Örneğin bir köy hanında bir kuyumcu kardeşi ve çırağı ile birlikte ticari faaliyette bulunmaktaydı ${ }^{63}$.

58 İncelediğimiz nüfus defterlerinin bir kısmında gurbetçi ile bir daha geri dönmemek üzere ocağını terk edenleri ayırt edebilmekteyiz. Örneğin, 5613 numaralı ve Hicri 1257 tarihli nüfus defterinde kesin ayrılanlar hicretle temekkün, hanesi ile gitti, tavattun etti, iskan etti, Selanik'e hicret etti ve tavattun etti, validesiyle beraber gitti ifadeleriyle vurgulanmıştır.

59 BOA, $N f$ s.d, nr. 5614.

60 Karpat, a.g.e., s. 149.

61 BOA, $N f$ s.d, nr. 5715.

62 BOA, Nfs.d, nr. 5694: Köstendil kasabası ve kazasında berayı ticaret üzere bulunan yabancı reaya (1262).

63 BOA, $N f$ s.d, nr. 5684, 5683. 
Kasabada tespit ettiğimiz kadarıyla yabancı nüfusun ekseriyeti gayrimüslim idi. Bununla beraber yabancı statüde Müslim nüfus da mevcuttu. Kasabada İştip, Yakova ve İvranyalı 6 müslim ve evlad-l Arap lakaplı aslen Medineli bir aile mevcuttu. Bu aile Pazarcık'tan Köstendil'e gelip Derviş mahallesine yerleşmiştir. Bir diğer kişi eğitim amaçlı gelmiş olup Cuma mahallesindeki mektebe yerleşmiştir. Beraberinde oğlu da bulunmaktaydı ${ }^{64}$.

5685 ve 5686 numaralı defterlere göre Köstendil kasabası gayrimüslim sakinlerinden İstanbul, Belgrat, Detgova, Filibe, Hamit kasabasına ticari faaliyette bulunmak üzere gidenler olduğu gibi bir aile de Dobnice'nin köyüne yerleşmiştir. Kasabadan ayrılanların kahir ekseriyeti geçimini temin etmek veya ticari faaliyette bulunmak üzere İstanbul'a gitmiştir. Kayıtlara göre Köstendil kasabasından 124 kişi ayrılmış, bunun 72'si ticari faaliyette bulunmak ve 42'si geçimini temin etmek maksadıyla İstanbul'a gitmişti. Gidiş süreleri 6-8 yıl arasında değişmekteydi. Kasabayı terk edenlerin çoğunluğu tek başına gurbete çıkarken bir kısmı kardeşi veya oğlu ile gitmiştir. Köstendil’i terk edenlerden 1 'i ala, 101'i evsat ve 22'si edna derecesinde cizye mükellefiydi. Bunların bir kısmının memlekette üvey kardeşi, kayını, oğlu, babası, muhtemelen eşi ve kız çocukları bulunurken bir kısmının ise hiç kimsesi yoktu. Bu gibiler vergilerini çalıştıkları yerde vereceklerini beyan etmişlerdir. Köstendil'in köylerinden ayrılan gayrimüslimlerin toplam sayısı ise 705 erkektir. Bunlardan 16'sının gittiği yer tespit edilememiş, Palanka, Yanya ve Siroz'a birer kişi, Menlik ve Minka'ya 3'er kişi, Radomir'e 80, Doniçe'ye 80, Leskofça'ya 78, İvranye'ye 90, Niş’e 18, Koçana'ya 29 ve İstanbul'a 275 kişi gitmiştir. İstanbul'a gidenlerden 203 'ünün amacı ticari faaliyette bulunmak, 72'sinin amacının ise bir iş bulup çalışmak olduğu anlaşılmaktadır. Köstendil'in kırsalından ayrılan 705 kişiden 394 'ü evsat, 137 'si edna ve 172 'si sıbyan, 2'si ise amelmande statüsündedir. İstanbul dışına gidenlerin ailece yer değiştirdikleri anlaşılmaktadır.

\section{Kratova}

Nüfus defterine göre 405'i gayrimüslim, 628'i Müslim olmak üzere Kratova kasabasının erkek nüfusu 1.097 kişidir. Gayrimüslimler iki, Müslümanlar beş mahallede ikamet ediyorlardı. Gayrimüslim erkeklerin 351'i yetişkin ve 134'ü çocuk yaştaydı. Kasabadaki Kıpti nüfus 55'i Müslim ve 9'u Hristiyan olmak üzere 64 erkektir ${ }^{65}$. Ayrıca kasabada kadı, zabitan, sekban gibi kamu hizmetinde çalışan 27 kişi vard ${ }^{66}$. Kasaba dahilinde 6 tane yabancı statüde gayrimüslim erkek bulunmaktaydı.

64 BOA, $N f s . d$, nr. 5683, 5684: Köstendil Mahallatında Bulunan Yabancı Ehl-i İslam ile Evlatlarının Mübeyyen Tahrir Defteri. Arap kökenli muhacirler evlad-ı Arap olarak tanımlanmıştır. Güven Dinç, "Osmanlıdan Cumhuriyete Antalya’ya Olan Göçler ve Sonuçları (1800- 1923)”, Geçmişten Günümüze Göç, 1, Samsun 2017, s. 763-780.

65 BOA, $N f s . d$, nr. 5715.

66 BOA, $N f$ s.d, nr. 5714. 
1830'lu yıllarda kazanın sınırları dahilinde 30 köy, 13 çiftlik ve 1 manastır bulunmaktaydı. Bu yerleşmelerde ve kurumlardaki yetişkin Hristiyan erkek nüfusun 1.947'si orta, 458'i düşük gelir grubundaydı. $775^{\prime}$ i ise çocuk yaştaydı. Ayrıca 54 Kıpti erkek vardı ${ }^{67}$.

Kaza halkının geçim kaynağı genelde tarım idi. Kasaba ahalisi ise çiftçiliğin yanı sıra debbağlık, muytaplık, terzilik ve dülgerlik gibi zanaat veya ticaretle uğraşmaktaydı ${ }^{68}$.

\section{Kumanova}

Kasaba Vardar'ın kolu Kriva suyu üzerinde inşa edilmiştir. A. Boue kasabanın nüfusunu 1836'da 3 bin kişi olarak verir. Kasaba yün ticaretiyle oldukça canlı bir pazar noktasıydı. 1844 tarihli temettü kayıtlarına göre ise Kumanova kasabası 498 haneden oluşmaktaydı. Bunun yarısı Müslim diğer yarısı gayrimüslim nüfustu ${ }^{69} .5715$ numaralı nüfus defterine göre Kumanova kasabasındaki gayrimüslim erkeklerin 290’1 yetişkin, 144’ü çocuk idi. Yetişkinlerin 8'i yüksek, 173 'ü orta ve 109 'u düşük gelir grubundaydi ${ }^{70}$.

Kazanın kırsalındaki 72 köy ve 3 çiftlikte 127'si ala, 1.640'ı evsat, 2.567'si edna ve 1.964'ü çocuk olmak üzere toplam 6.298 gayrimüslim erkek mevcuttu. Ayrıca kaza dahilindeki reayanın bir kısmı da madenci ve sair hizmet erbabı statüsündedir. Bu yerleşmelerdeki erkek reaya nüfusu 3.572 kişidir ${ }^{71}$. Kazanın nüfusu 1831'de 2.276'sı Müslim, 10.819'u reaya olmak üzere 13.094 erkekten oluşmaktayd ${ }^{72}$. Temettüat verilerine göre 1844 'de kaza nüfusunun \%26.23'ü Müslim, \%73.77'si gayrimüslimdi³

1844 temettüat kayıtlarına göre Kumanova kazasına 10'u karma, 85'i gayrimüslim, 14'ü Müslim olmak üzere toplam 109 köy tâbiydi. Kaza dahilindeki yerleşmelerde 1.143'ü Müslim, 3.214 'ü gayrimüslim olmak üzere toplam 4.357 hane mevcuttu. Kaza nüfusunun \% 78.54 'ü çiftçi, \% 7.04'ü tüccar ve zanaatkâr, \%6'sı ırgat, hizmetkâr, yarıcı, aylakçı, sairleri yetim, sabi ve fukara grubuna dahildi. Fakir halkın bir kısmı konu komşunun yardımları ile geçimlerini temin ediyorlardı. Büyük tarım arazilerine sahip kişiler de mevcuttu. Bunlar sahibi olduğu arazinin üzerinde veya kasabada ikamet ediyordu. İkamet ettiği yerleşmenin dışında da arazisi olan vardı. Kaza dahilindeki mülk sahibi 94 kişinin ikametgâhının bulunduğu köyün dışında 29 farklı köyde de gayrimenkulleri bulunmaktayd $1^{74}$. Çiftlikler kiraya verildiği gibi, ortakçılık yöntemiyle veya hizmetkârların emek gücüyle işletiliyordu. Üç emek gücünden istifade eden çiftlik sahibi de mevcuttu.

67 BOA, Nfs.d, nr. 5715.

68 Kosova Vilayeti Salnamesi 1318, s. 318.

69 Machiel Kiel, "Kumanova", DIA, c. XXVI, Ankara 2002, s. 363-364.

70 BOA, $N f s . d$, nr. 5715.

71 BOA, Nfs.d, nr. 5715.

72 Karpat, a.g.e., s. 149.

73 Ali Aslan, Temettüat Kayıtlarına Göre 19. Yüzyllın Ortalarında Kumanova Kazasında Nüfus, Yerleşim ve Ekonomi, Yayınlanmamış Yüksek Lisans Tezi, İstanbul 2016, s. 33.

74 Aslan, s. 30-33. 
Tüccar ekseriya Köprülü üzerinden Üsküp’ten ve bazen Selanik’ten getirdiği malı Kumanova'da pazarlamaktaydı. Civar kazalardan da pek çok tüccar kasaba pazarına gelmekteydi. Köylüler alışveriş ihtiyacını Kumanova pazarından karşılıyorlardı. Bununla beraber alışveriş için Üsküp, Preşuh, İştip, Kratova, Palanka ve Bereketli kasabalarına gidenler de oluyordu ${ }^{75}$.

Kasaba ve köyler kaza dahilindeki diğer yerleşmelerden veya kaza sınırları dışındaki yerleşmelerden nüfus göçü almıştır. Kumanova kasabası ve tâbi köyler Niş, Debre, Yanya, Zagor, İşkodra, Köprülü, Pirlepe, İvranye, Hırsova, Manastır ve Kalkandelen'den nüfus çekmiştir. Temettüat defterlerindeki memleket ve lakaplardan anlaşıldığına göre kasaba dahilinde yabancı statüsünde Arap, Arnavut, Boşnak, Karadağlı, Mısırlı, Pomak, Tatar, Üsküplü bulunmaktaydı. Kasabada 1'i ala, 39'u evsat ve 3'ü edna statüde toplam 43 yabancı reaya vard ${ }^{76}$. Bunlardan dördünün memleketleri ile Kumonova arasında sürekli gelip gittiğine dair kayıtlar bulunmaktadır ${ }^{77}$. Köylerdeki yabancı gayrimüslimler 34 kişiydi. Yabancı reayanın 7'i ala, 22'si evsat ve 5'i edna statüsündeydi. Sıbyan ve amelmandeler de dahil edildiğinde kazadaki yabancı gayrimüslim nüfus 80 kişiyi buluyordu ${ }^{78}$.

Kasabadaki yabancı gayrimüslim ahali çömlekçilik, hancılık, tüccarlık, kalaycılık, hizmetkârlık, yemenicilik, kuyumculuk ve kazancılık yapmak suretiyle geçimlerini temin ediyorlardı. Bunlar çoğunlukla mevcut hanlarda ikamet ediyorlardı. Temettüat kayıtlarına göre kasaba dahilinde 9'u Müslümanlara, 2'si gayrimüslimlere ait 11 han bulunmaktaydi ${ }^{79}$. Hancı ve kalaycılardan bir kısmının yanında oğlu, yeğeni, çırağı, kalfası ve hizmetkârı bulunmaktaydı. Yanlarında çalıştırdıkları kişiler farklı yerlerden gelmiştir. Kumanova'nın 7 köyünde yabancı nüfus mevcuttu. Bunların çoğunun mesleği belirtilmemiştir. Mesleği belirtilenlerin hancılık ve hizmetkârlık ile geçimlerini temin ettikleri anlaşılmaktadır. Köylerdeki yabancı reayanın bir kısmı beraberinde ailesini de getirmiştir. Hancı ticaretiyle meşgul olanların bir kısmının yanında hizmetkârı da bulunmaktaydı ${ }^{80}$.

Kumanova kasabasında yabancı Müslim nüfus da vardı. 1831 tarihli 5702 numaralı nüfus defterinde Kumanova'da yabancı Müslim nüfus olarak 37 kişi kayıtlıdır. Yabancı nüfus içinde naip, ayan gibi yüksek rütbeli kamu görevlileri ve bunların yanında istihdam ettikleri personel bulunmaktaydı. Kumanova Ayanı İsmail Bey 1828'de Üsküp’ten gelmiş, maiyetinde Zamir, Üsküp, Kalkandelen, İvranye, Mora ve Debreli eşkinci sipahisi, hizmetkâr, bölükbaş1, sekban unvanlı şahıslar mevcuttu. Bu şahısların bir kısmı ayanla birlikte gelmiş, bir kısmı

75 Kosova Vilayeti Salnamesi 1318, s. 400.

761831 tarihli 5702 numaralı nüfus defterine göre Kumonova'da bulunan yabancı gayrimüslim nüfus 39 kişidir.

77 Sead Abazi, 15377 ve 15463 Numaralı Temettuat Defterlerine Göre 19. Yüzyılda Kumanova Kazası'nın SosyoEkonomik Yapısı, Yayınlanmamış Yüksek Lisans Tezi, Bursa 2016, s. 17.

78 BOA, Nfs.d, nr. 5703.

79 Abazi, s. 17.

80 BOA, $N f s . d$, nr. 5703, Kumonova Kasabası Yabanciyan Reaya. 
ise daha sonra gelip ayanın hizmetine dahil olmuştur. Üsküplü Baki de Kumanova’ya ayan olduğu zaman beraberinde bazı kişileri maiyetinde çalışmak üzere Üsküp’ten getirmişti. İleriki tarihlerde de ayana kapılanan Üsküplüler olacaktır. Örneğin bir sene önce kasabaya gelip sekbanlık yapan 6 Üsküplü vard1 ${ }^{81}$.

\section{Palanka}

Vardar'ın kolu Kriva suyu üzerinde kurulmuş bir yerleşmedir. Kasaba sadrıesbak Bayram Paşa tarafından 1615 yılında kale harabesi üzerine inşa edilmiştir. Zamanla etraftan gelenlerle kasaba halini almıştır ${ }^{82}$. Osmanlı kaynaklarında Eğridere şeklinde geçer. Daha sonra Eğridere Palankası adı yaygınlaşmıştır ${ }^{83}$. Kasaba 1875 'e kadar nal imalatı ile markalaşmıştı. Ancak Avrupa ülkelerinin bu alandaki rekabeti kasabadaki nal zanaatını sekteye uğratmıştır ${ }^{84}$.

Kratova, İvranye ile birlikte Palanka'nın nüfusu 4.749'u Müslim, 21.068'i reaya ve 627'si Kıpti olmak üzere 36.464 erkektir $^{85}$. 1831 tarihli nüfus icmal defterine göre kasabadaki yerli erkek nüfus 199 kişiydi. Palanka kasabasında 39'u büyük, 12'si küçük olmak üzere toplam 87 Müslim Kıpti erkek de bulunmaktaydı. Gayrimüslim Kıptiler ise kazanın kırsalında ikamet etmekte olup toplam 36 erkektir. Kasaba dahilinde 148'i yetişkin ve 51'i çocuk olmak üzere toplam 199 gayrimüslim erkek nüfus mevcuttu. Kasaba ve köylerdeki misafir hanlarında 19 yabancı gayrimüslim erkek vardı. Bunun üçü dükkân sahibi Yahudi idi ${ }^{86}$. Kırsal alanda çiftlik ve köyler mevcuttu. Gayrimüslim nüfusun ikamet ettiği köy sayısı 55, çiftlik sayısı ise 11'dir. Bölgedeki çiftliklerin ayrıca ele alınıp incelenmesi gerekmektedir. Çünkü icmal defterinde Rankofça köy statüsünde gösterilirken yanına düşülen şerhte buranın Palanka ağalarından kale serdarı Numan Bey'in çiftliği olduğu ifade edilmekteydi ${ }^{87}$. Çiftliklerde 639, köylerde 5.298 gayrimüslim erkek ikamet etmekteydi ${ }^{88}$.

Ahalinin ekserisi ziraatla, 200 hanesi ortakçılık ile geçimini temin ediyordu. Her yıl 1.500 kadar Palankalı Bulgaristan ve Romanya'ya gidip 6 ay kadar 1rgatlık yapmaktayd ${ }^{89}$. Nüfus defterlerinden anlaşıldığı kadarıyla Palanka kasabası dahilinde Manastır, Kratova, Zagor, Şehirköy, Köstendil, Yanya, Siroz, Şarköy ve Kumanovalı Rum nüfus vardı. Bunlar tespit edebildiğimiz kadarıyla kuyumculuk, terzilik, boyacılık, hancılık, kürekçilik, çömlekçilik, papuçculuk, bakkallık yapmaktaydılar. Bunlardan 9'u zamanla geri dönmüştür. Geri dönenlerin Palanka'da bulundukları süre 5 ile 35 yıl arasında değişmektedir. Kasabaya

81 BOA, $N f$ s.d, nr. 5702.

82 Kosova Vilayeti Salnamesi 1318, s. 461.

83 Machiel Kiel, “Eğridere Palankası”, DİA, Ek 1, İstanbul 2016, s. 393-395.

84 Kosova Vilayeti Salnamesi 1318, s. 461.

85 Karpat, a.g.e., s. 149.

86 BOA, $N f$ s.d, nr. 5715.

87 BOA, $N f$ s.d, nr. 5715 (15 N 1246).

88 BOA, $N f$ s.d, nr. 5715.

89 Kosova Vilayeti Salnamesi 1318, s. 461. 
gelenlerin bir kısmı zamanla kasaba dahilinde mahallesini değiştirmiştir. Bazı ailelerde ilk önce hane reisi kasabaya gelmiş, bir süre sonra münavebeli bir şekilde erkek çocuklarını yanına almıştır. Örneğin, 1817'de Zagor kazasından bir kişi Palanka'ya gelmiş, 20 yıl sonra bir oğlunu, 22 yıl sonra da diğer oğlunu Palanka’ya getirtmiştir. İkinci çocuğun gelişinden on y1l sonra baba, bir yıl sonra da çocuklar geri dönmüştür. Bir kişi kardeşinin oğlu ile gelmiştir. Kendisi çömlekçilik, yeğeni hizmetkârlık yapmak suretiyle yaşamını idame ettirmekteydi. Bunlar 25 yıl Palanka'da ikamet edip geri dönmüşlerdir. Bir çömlekçi ustası ise iki kalfası ile birlikte kasabaya gelmiş ve aynı yıl geri dönmüştür. Muhtemelen çömlek ticareti yapıyorlard $1^{90}$. Kasaba dahilindeki Tekke-i kebir bahçelerinde 8 bahçıvan, birer enfiyeci kalfası, simitçi, boyacı, meyhaneci, semerci, hekim, çırağı ve hademesi ile birlikte bulunmaktayd1 $1^{91}$.

Kaza dahilindeki yabancı nüfus arasında Müslim ve gayrimüslim Kıpti nüfus da vardı. Kasabanın Behrampaşa mahallesinde 66, kazaya bağlı bir köyde de 11 Müslim Kıpti bulunmaktaydı. Öte yandan on köyde 98, 2 çiftlikte 10 gayrimüslim Kıpti nüfus vard $1^{92}$.

Palanka kasabası ve kırsalından dışa göç de hiç şüphesiz gerçekleşmiştir. Bu göçleri sayısal açıdan gerçek boyutta ortaya koymak mümkün değil. Bununla beraber dışa göç konusunda bir fikir verebilmek açısından mahall-i ahara gidenler ve nüfus yoklama defterleri kaynaksal verileri ihtiva etmektedir. 1842 tarihli Eğridere Palanka kazasına ait 5637 numaralı nüfus defterinde kazayı terk eden 4 Müslüman, 37 gayrimüslim erkek ile ilgili kayıt bulunmaktadır. Bu kayıtlara göre Müslümanlardan birisi hanesiyle Kratova’ya gitmiştir. Geride kardeşi kalmıştır. 60 yaşındaki Mustafa ise ailesiyle Sofya'ya gitmiş olup onun Palanka'da herhangi bir akrabası kalmamıştı. Üçüncü şahıs ise muhtemelen ailesini memlekette bırakarak ticari maksatla Anadolu'ya gurbete gitmiştir. Deftere kayıtlı 37 gayrimüslimin yaşları 17 ile 55 arasında değişmektedir. 16'sı Palanka kasabasında, 2'si Palanka kazası dahilindeki iki çiftlikte, arta kalanlar ise 7 köyde ikamet etmekteydi. Bunların 18'i ticari maksatla başta İstanbul olmak üzere Donuca, Bosna, Belgrat'a gitmişlerdir. Kazayı terk edenlerin bir kısmında ise gidiş sebebi belirtilmemiştir. Göç edenlerin bir kısmının memleketinde herhangi bir yakını kalmazken, bir kısmının ise eşi, kız çocukları, babası, kardeşi bulunmaktaydı. Defterde kadın nüfus hakkında bilgi olmamakla beraber eş ve kız çocukları birlikte gelenlerin isimlerinin yanına hanesi ibaresi kaydedilmiştir. Gurbetçilerin vergileri geride kalanlarca ödenmekteydi. Örneğin bir gurbetçinin sütununda bir sene önce ticari maksatla Ístanbul'a gitmiş olup cizyesi hanesi tarafindan eda edildiği kaydı vardır ${ }^{93}$.

$90 \quad$ BOA, $N f s . d$, nr. 5639.

91 BOA, $N f s . d$, nr. 5576, Kalkandelen Yabanc1 Defteri Reaya.

92 BOA, $N f s . d$, nr. 5638, Palanka kasabasında ve kurasında bulunan İslam ve Reaya Kıptilerin esami defteri.

93 BOA, $N f s . d$, nr. 5637, Rumeli Eyaleti Köstendil Kaimekamlığı İdaresinde Bulunan Eğridere Palangası'nın mahall-i ahar defteri. (5636 numaralı defterle içerik açısından örtüşmektedir. Bu defterde farklı olarak bir köy ve iki çiftlikten ayrılan beş erkek ile ilgili bilgiler yer almaktadır. BOA, $N f s . d$, nr. 5636, Rumeli Eyaleti Köstendil Kaimekamlığı İdaresinde Bulunan Eğridere Palangasının mahall-i ahar defteri. 


\section{Radovişte}

Radovişte kazasının nüfusu 1831 sayımına göre 13.504'ü Müslim ve 4.907 gayrimüslim olmak üzere toplam 8.411 erkektir. Kadın erkek nüfusun eşit olduğu varsayımından hareket edecek olursak kazanın nüfusunun 8.900'e yaklaştığını söyleyebiliriz ${ }^{94}$. Halkın çoğunluğu ziraatla meşguldür. Her yıl Mayıs-Ekim ayları arasında Selanik, Köprülü ve sair yerlerden gelen tüccarlar buradan hayvan ve tahıl satın alırlard $1^{95}$.

Kazanın merkezi Radovişte kasabasıdır. Mevcut yabancı nüfus kamu görevlileri ve onların yanlarında istihdam ettikleri kişilerdir. İlgili deftere göre kasaba dahilinde 24 yabancı Müslim nüfus mevcuttur. Bunlar kazanın mülki amiri müdür ile maiyetinde çalışan beş kişidir. Bir diğer yabancı Müslim kazanın naibi, naibin kardeşi, yeğeni ve maiyetinde bulunan iki kişidir. Bunların birisi Tırnova'dan gelmiş, diğerlerinin geldiği yer kaydedilmemiştir. Ayrıca kasabada Berat ve Debreli yedi süvari bulunmaktaydı. Manastır'dan gelme üç kişi mevcuttu. Kamu görevlileri dışında ilgili nüfus defterlerine yansıdığı kadarıyla kasabada beraberinde oğlu ve çalışanı olduğu halde Prizren'den gelme bir helvacı bulunmaktayd $1^{96}$.

Aynı tarihlerde Radovişte kasaba ve kırsalından dışa göç hareketleri ile ilgili mahall-i aharda bulunanlar defterlerinde birçok veriye ulaşabilmekteyiz. Kasabadan 18'i yetişkin, 3'ü çocuk ve 8'i yaşlı olmak üzere 29 Müslim erkek dişa göç etmiştir. Bunlar Edirne, Doniça, Siroz, Debre-i Bala, Tikveş, Temurhisar, Pazarcık, Manastır, Ustrumca, İstanbul ve Anadolu'ya gitmişlerdir. Deftere yansıdığı kadarıyla bunların göç sebepleri voyvoda, ayan gibi kamu görevlilerinin tabiiyetinde çalışmak, eğitimini sürdürme arzusu, ticari faaliyette bulunmak, diğer yerleşmelerdeki tarikatlara intisap etmekti. Bir diğer ayrılış sebebi Asakir-i Mansure-i Muhammediye birliklerine katılmaktı. Bir de şehirden kesin olarak ayrılanlar vardı. Bu gibiler aileleriyle kasabayı terk edip bir diğer yerleşmeye gidip iskan ediyordu. Radovişte'nin köylerini terk edenlerin bir kısmı Selanik, Pazarcık ve Doniçe gibi yerleşmelerde sekban, kır bölükbaşısı görevlerinde istihdam edilmişlerdir. Öte yandan suç işleyenlerin bir kısmı da kanuni takibattan kurtulmak amacıyla firar etmişti. $\mathrm{Bu}$ gibilerin bulundukları yerlere dair herhangi bir bilgi edinilememiştir. Radovişte kasaba ve köylerinden bir diğer ayrılma sebebi hac farizasını yerine getirmek amacıyla Hicaz'a gerçekleştirilen yolculuklardır. Nüfus defterlerine göre Radovişte'nin köylerini terk eden Müslüman erkeklerin 25'i yetişkin ve 10'u yaşlı olmak üzere toplam 30 kişidir. Bunlar Pazarcık, Filibe, Hicaz, Samakov ve İstanbul'a gitmişlerdi ${ }^{97}$. Kasabanın gayrimüslim sakinlerinden 1 çocuk, 18 edna ve 36 evsat, köylerden ise 37 çocuk, 1 edna ve 104 evsat

94 Karpat, a.g.e., s. 149.

95 Kosova Vilayeti Salnamesi 1318, s. 449.

96 BOA, $N f s . d$, nr. 5712, Radovişte Kasabasındaki Yabancı Ehl-i İslam.

97 BOA, $N f s . d$, nr. 5613. 
statüsündeki reaya ticaret, serseri, tebaalık yapmak için veya naklhane statüsünde Filibe, Ustrumca, Petric, Belgrat, Siroz, Selanik, Bursa, Kesendire, Eğridere Palanka, Köprülü’ye gitmişlerdir ${ }^{98}$.

\section{Sonuç}

Ülke sınırları dahilinde geçici ve daimi surette yer değiştirme hareketine iç göç denir. Yer değiştirme hareketini serbest ve zorunlu yer değiştirme olmak üzere ikiye ayırabiliriz. Sürgün, nakil, tebid ve tehcir siyasi otoritenin kararı ile gerçekleşir. Kişi geçimini sağlama, eğitimini sürdürme, siyasi baskılardan kurtulma, doğal afetlerden korunma, sosyal yaşam tarzını iyileştirme gibi sebeplerle de yer değiştirir. Bu değişikliğe birey kendi iradesiyle karar verir.

Makalenin sınırları içerisinde yer alan idari birimlerin kırsalında yaşayanlar görece tarımsal faaliyetlerle geçimlerini temin ediyorlardı. Geçim sıkıntısı çeken aileler çözümü gurbette arayabilmişlerdir. Rızkını kamusal alanda istihdamda bulanlar olmuştu. 1830'lu yıllar kapı halkı anlayışının tasfiye edildiği ve bürokratik anlayışın ortaya çıkıp yaygınlaştığı bir zaman dilimidir. Bu dönemde kasaba ve şehirlerde mutasarrıf, naip, ayan gibi idarecilerin hizmetinde birçok kişi bulunmaktaydı. Bu alanda yerli halktan daha ziyade yabancı nüfus istihdam edilmiştir.

Köyünü terk edenlerden müteşebbis ve zanaata yetenekli olanlar kendilerine en yakın kasabaya atıp bir baltaya sap olmak amacıyla bir ustanın yanına çırak olarak girdiklerini anlıyoruz. Bu gibiler kasabadaki medrese, mektep, zaviye ve tekke gibi kamu binalarında, hanlarda veya çalıştıkları dükkânların üstündeki odalarda, hatta dükkânda barınmaktaydılar. Ustalarının evinde ikamet edenler de vardı. Bu şekilde çıraklıktan kalfalığa, kalfalıktan ustalığa terfi ediyorlardı. Bu gibiler arasında ileride kendi iş yerlerini açanlara bile tesadüf edilmiştir.

Köyünü terk edenlerden bir kısmı da inşaat sektöründe istihdam olmuştur. Dülger, duvarcı, kiremitçi gibi inşaat amelesi çalışmak amacıyla eyalet veya kaza merkezi olan kasaba ve şehirlere gidebildikleri gibi soluğu başkent İstanbul'da alanlar da oluyordu. Hatta Romanya ve Bulgaristan'a gidip gelenler bile vardı. Başkentte ve taşrada vakıf ve kamu adına yapılan inşaatlarda ücretli usta ve amele istihdam edilmiştir. Anadolu ve Rumeli'nin birçok yerleşmesinden İstanbul'a inşaat sektöründe çalışmak üzere mevsimlik amele gelmiştir. Bunlar ücretli idi.

Osmanlı Balkanı'nda zirai üretim iklim şartlarında gerçekleştiriliyordu. Bu nedenle üretim iklime göre yıldan yıla değişebilmekteydi. Hasadın azlığı veya çokluğu, mahsulün erken

98 BOA, $N f$ s.d, nr. 5614. 
veya geç olması emek gücünü de etkilemekteydi. Rekolteye göre emeğe duyulan ihtiyaç artıyor veya azalıyordu. Hasat vakti yerel idareciler mülkî ve askerî amirlerin koordinesinde amelenin sevki için gerekli tedbirleri alır ve mevsimlik işçileri amele açığı olan yerlere yönlendirmeye çalışırlardı1 ${ }^{99}$. Söz konusu trafik Balkanların siyasi haritası değiştikten sonra da milli sınırlar aşılarak devam edebilmiştir ${ }^{100}$.

Kasaba ve kura ahalisinden geçimini sağlayamayan ve herhangi bir zanaata sahip olmayan erkekler çözümü gurbetçilikte bulacaklardır. Müslim ve gayrimüslim ahali ticaret veya iş bulup çalışma çabası içine gireceklerdir. Fukara ahali gittikleri kasaba ve köylerde hizmetkârlık veya yanaşma statüsünde buldukları işlerde üç, beş yıl çalışmakta, bu iş kendilerini tatmin etmezse veya işveren tarafından kendisine yol verilirse tekrar iş aramakta ve bulduğu takdirde de çalışmaktadır. Osmanlı bürokratı bu gibi kişileri gezginci olarak tanımlamıştır. Bu gibi kişilerden bir kısmı ise bir süre memleketine dönmekte, dinlenmekte ve tekrar gurbete çıkmaktaydi ${ }^{101}$.

İç göçün bir diğer gerekçesi eğitim idi. Köyünden veya kasabasından ayrılanlar yakın bir yerleşme veya İstanbul'daki medreseye kapağı atabilmişlerdir. Medreselerde müderris, imam, müezzin, suhte, danişmend ve talebe unvanlı kişiler bulunmaktaydı. Medreselerde eğitim camiası dışında tüccar, tellak ve kahveci gibi tacir ve esnafin da ikamet edebildiği anlaşılmaktadır. Fakir talebeler bu gibi zanaatkâr ve tüccarın yemeğini pişirmek ve arkasını toplamak gibi ayak işlerini yaparak harçlıklarını çıkarabilmekteydiler ${ }^{102} .1792$ sayımına göre İstanbul'daki medreselerde toplam 2.803 kişinin barındığı anlaşılmaktadır. Bu talebelerden bir kısmı 15 yıl aynı hücrede barınabilmiş, baba-oğul aynı medresede ve hatta aynı hücrede ikamet edebilmiştir. 1844 tarihli defterden anlaşıldığı kadarıyla İstanbul'daki medreselerde 250 yerleşmeden kalkıp gelen 1.274 kişi vardı. Bunlardan 10’u Üsküplü, 8'i Koçanalı ve 13’ü Kalkandelenlidir. Bunların bir kısmı efendi unvanına sahipti. Söz konusu kişilerin yaşları 5 ile 55 arasında değişmekte olup yaş ortalaması $26.29^{\prime}$ dur $^{103} .437$ numaralı defter ise 1857-1858 tarihlidir. Bu defterde Kalkandelenli 19, İvranyeli 1 ve Köstendilli 2 kişinin adı kayitlidir ${ }^{104}$.

99 BOA, A.MKT.NZD, 84/23, Seraskerlik Makamına Şevval 1269. Amele göçü için bk. Nedim İpek, “2. Abdülhamid Döneminde Trabzon'da Amele Göçü”, Karadeniz Incelemeleri Dergisi, sayı 25, Trabzon 2018, s. $103-132$.

100 BOA, BEO, 1938/145312, Dahiliye Nezaretine Tezkire (7 TE 1318).

101 BOA, $N f$ s.d, nr. 5614.

102 Necati Aktaş, 1206 (1792) Tahririne Göre İstanbul Medreseleri, Yayımlanmamış Yüksek Lisans Tezi, İstanbul 1986, s. 172.

103 İbrahim Aydoğdu, 185 Numaralı Deftere Göre İstanbul Medreseleri Nüfusu (1844), Yayımlanmamış Yüksek Lisans Tezi, Samsun 2015.

104 Yahya Karakaya, 437 Numaralı Nüfus (Medrese Yoklama) Defterinin Transkribi ve Değerlendirmesi, Yayınlanmamış Yüksek Lisans Tezi, Elazı̆̆ 2016. 
Hakem Değerlendirmesi: Dış bağımsız.

Çıkar Çatışması: Yazar çıkar çatışması bildirmemiştir.

Finansal Destek: Yazar bu çalıșma için finansal destek almadığını beyan etmiștir.

Peer-review: Externally peer-reviewed.

Conflict of Interest: The author has no conflict of interest to declare.

Grant Support: The author declared that this study has received no financial support.

\section{Kaynakça/References}

\section{Arşiv Kaynakları}

Türkiye Cumhuriyeti Cumhurbaşkanlığı Devlet Arşivleri Başkanlığı Osmanlı Arşivi (BOA)

Bâb-1 âli Evrak Odası (BEO)

Sadaret

Mühimme Kalemi (A.MKT.MHM.)

Nezaret ve Devair Evrakı (A.MKT.NZD.)

Maliye Nezareti Varidat Kalemi Temettüat Defterleri (ML.VRD.TMT.d.), nr. 15471.

Nüfus Defterleri (Nfs.d.),

Nr. 5574, Kalkandelen Yabancı Reaya Defteri.

Nr. 5576, Kalkandelen Yabancı Reaya Defteri.

Nr. 5580, Kırçova Yabancı Müslim Tüccar Defteri.

Nr. 5583, Kırçova Yabancı Reaya Defteri.

Nr. 5605, Köprülü Yabancı Reaya Defteri.

Nr. 5608, Üsküp Sancağından Diyar-1 Ahara Gidenler.

Nr. 5612, H. 1254 tarihli Üsküp Yabanc1 Ehl-i İslam Defteri.

Nr. 5613, Üsküp, İştip, Radovişte, Kırçova, Köprülü Kazaları Sükkanından Olup Ticaret ve Misafiretle Kaza-yı Ahara Giden Müslim Defteri.

Nr. 5614, Üsküp, İştip, Radovişte, Kırçova, Köprülü Kazaları Sükkanından Olup Ticaret ve Misafiretle Kaza-yı Ahara Giden Reayanın Defteri.

Nr. 5619, Üsküp Sancağı Karşıyaka, Çayırova, Karadağ Kolu Yabancı Reaya Defteri.

Nr. 5623, Kalkandelen Nüfus İcmal Defteri.

Nr. 5624, Üsküp Nüfus İcmal Defteri.

Nr. 5636, Köstendil'den Diyar-1 Ahara Gidenler.

Nr. 5637, Eğriderepalankası Kazası Mahall-i Aharda Bulunan Defteri.

Nr. 5638, Palanka Kasabasında ve Kurasında Bulunan İslam ve Reaya Kıptilerin Esami Defteri.

Nr. 5639, Palanka Kasabasındaki Yabancı Zanaatkâr ve Tüccar Defteri.

Nr. 5663, İvranye Müslim Kıpti Defteri.

Nr. 5664, İvranye Yabancı Gayrimüslim Defteri. 
Nr. 5669, Koçana Yabancı Müslim Defteri.

Nr. 5670, Koçana Yabancı Reaya Defteri.

Nr. 5683, Köstendil Yabancı Müslim Defteri.

Nr. 5684, Köstendil Yabanc1 Müslim Defteri.

Nr. 5685, Köstendil'den Mahall-i Aharda Bulunan Reaya Defteri.

Nr. 5686, Köstendil'den Mahall-i Aharda Bulunan Reaya Defteri.

Nr. 5694, Köstendil Yabanc1 Reaya Defteri

Nr. 5698, Kratova Yabancı Rum Reaya Esnaf ve Zanaatkârları Defteri.

Nr. 5702, Kumanova Yabanc1 Müslim Defteri.

Nr. 5703, H. 1246 Kumanova Yabancı Reaya Defteri.

Nr. 5712, Radovişte Kasabasındaki Yabancı Ehl-i İslam Defteri.

\section{Kitabi Kaynaklar}

Abazi, Sead, 15377 ve 15463 Numaralı Temettuat Defterlerine Göre 19. Yüzyılda Kumanova Kazası'nın Sosyo-Ekonomik Yapısı, Yayınlanmamış Yüksek Lisans Tezi, Bursa 2016.

Aktaş, Necati, 1206 (1792) Tahririne Göre Istanbul Medreseleri, Yayımlanmamış Yüksek Lisans Tezi, İstanbul 1986.

Aslan, Ali, Temettüat Kayıtlarına Göre 19. Yüzyılın Ortalarında Kumanova Kazasında Nüfus, Yerleşim ve Ekonomi, Yayımlanmamış Yüksek Lisans Tezi, İstanbul 2016.

Aydoğdu, İbrahim, 185 Numaralı Deftere Göre İstanbul Medreseleri Nüfusu (1844), Yayımlanmamış Yüksek Lisans Tezi, Samsun 2015.

Demirel, Derya, Siroz Sancă̆̆’nın Sosyo-Ekonomik Yapısı (1876- 1912), Yayımlanmamış Doktora Tezi, Samsun 2016.

Dinç, Güven, “Osmanlıdan Cumhuriyete Antalya’ya Olan Göçler ve Sonuçları (1800- 1923)”, Geçmişten Günümüze Göç, 1, Samsun 2017, s. 763-780.

Furat, Ahmet Hamdi, Temettuat Defterlerine Göre Üsküp'ün Sosyal ve Ekonomik Tarihi, Yayımlanmamış Yüksek Lisans Tezi, İstanbul 2001.

Gül, Emine, 19. Yüzyılda Makedonya ve Üsküp Kazası, Yüksek Lisans Tezi, İstanbul 1999.

İpek, Nedim, “2. Abdülhamid Döneminde Trabzon'da Amele Göçü”, Karadeniz Íncelemeleri Dergisi, sayı 25, Trabzon 2018, s. 103-132.

Karaduman, Gökay, Temettuat Defterleri Çerçevesinde Koçana / Üsküp Kazasının Sosyal ve Ekonomik Yapısı, Yayımlanmamış Yüksek Lisans Tezi, İstanbul 2014.

Karakaya, Yahya, 437 Numarall Nüfus (Medrese Yoklama) Defterinin Transkribi ve Değerlendirmesi, Yayınlanmamış Yüksek Lisans Tezi, Elazı̆̆ 2016.

Karpat, Kemal, Osmanlı Nüfusu, İstanbul 2003.

Kiel, Machiel, “Eğridere Palankası”, DİA, c. Ek 1, İstanbul 2016, s. 393- 395. , "İştip”, DİA, c. XXIII, İstanbul 2001, s. 440- 442. "İvranye", $D \dot{I} A$, c. Ek 1, İstanbul 2016, s. 683- 686. 
, “Kumanova”, DIA, c. XXVI, Ankara 2002, s. 363-364.

Kosova Vilayeti Salnamesi 1318.

Osmanlı Belgelerinde Kosova Vilayeti, İstanbul 2007.

Yağc1, Zübeyde Güneş, “18. Yüzyılda Osmanlı İnşaat Sektöründe Gayri Müslimler ve Kafkasya’ya Gönderilen Ermeni Ameleler”, Ermeni Araştırmaları, II/7 (2002), s. 41- 54.

Yiğit, İlker, “Anadolu Kırsalında Göçün Dünkü (16-20. Yüzyıllar) Yapısı: Manisa ve Konya Çevresi Üzerinden Bir Göç Okuma Denemesi”, Erdem, sayı 76, Ankara 2019, s. 205-244.

Zorba, Hatice Akın, “1833 Tarihli Nüfus Defterine Göre Üsküp Kazasının Demografik Yapısı”, Mediterranean Journal of Humanities, VIII/1 (2018), s. 23-40. 